\title{
Chemical and environmental compatibility of red mud liners for hazardous waste containment
}

\author{
D. A. Rubinos ${ }^{1}$ G. Spagnoli ${ }^{2,3}$ - M. T. Barral ${ }^{1}$
}

Received: 23 March 2015/Revised: 25 September 2015/Accepted: 1 December 2015/Published online: 7 January 2016

(C) Islamic Azad University (IAU) 2015

\begin{abstract}
Red mud residue from alumina production has been proposed as an alternative liner material. The chemical and environmental compatibility of red mud upon exposure to representative organic (methanol, heptane, TCE, and acetic acid) and inorganic liquids $\left(\mathrm{CaCl}_{2}\right.$ and seawater) was studied. Chemical compatibility assays comprised Atterberg limits and sedimentation and hydraulic conductivity tests for red mud interacted with the chemical liquids, whereas the environmental compatibility was assessed through the leaching of metals from red mud as permeated with the liquids. Methanol greatly reduced the plasticity at concentrations $\geq 80 \%$ by volume, but it did not increase the hydraulic conductivity of compacted red mud. High concentrations $(\geq 60 \% \mathrm{v} / \mathrm{v})$ of acetic acid reduced the plasticity and enhanced the sedimentation of red mud. Conversely, acetic acid concentrations $\leq 40 \%$ caused dispersion, but damaged the hydraulic properties and structure of red mud. The percolation of a $\mathrm{pH} 2$ acetic acid solution did not adversely affect the hydraulic performance of the red mud liner. Neither diluted heptane nor TCE affected the red mud. However, pure organics
\end{abstract}

Electronic supplementary material The online version of this article (doi:10.1007/s13762-015-0917-8) contains supplementary material, which is available to authorized users.

D. A. Rubinos

david.rubinos@usc.es

1 Departamento de Edafoloxía e Química Agrícola, Facultade de Farmacia, Universidade de Santiago de Compostela, Campus Vida, 15782 Santiago de Compostela, Spain

2 Department of Maritime Technologies, BAUER Maschinen $\mathrm{GmbH}$, Schrobenhausen, Germany

3 School of Civil, Structural and Environmental Engineering, University College Dublin, Dublin, Ireland suppressed the plasticity and induced aggregation of red mud, suggesting a great detrimental effect on red mud liners. The red mud exhibited great resistance to attack by inorganic salt solutions. Some concerning leaching of metals (primarily $\mathrm{Al}$ and $\mathrm{Cr}$ ) occurred as water, acetic acid, and $\mathrm{CaCl}_{2}$ solutions percolated through red mud, but effluent metals concentration quickly dropped to permissible levels. In general, red mud exhibited a high resistance against chemical attack; nevertheless, exposure to low-dielectric-constant organic chemicals should be avoided.

Keywords Bauxite waste - Barrier .

Hazardous chemicals · Permeability · Leaching ·

Environmental impact

\section{Introduction}

Proper disposal and storage of hazardous waste require their isolation to prevent migration of leachates from the waste into the surrounding areas and to safeguard the soil and water against the possible contamination by infiltration of toxic pollutants from the waste, ultimately protecting the public health. To this aim, mineral liners or "compacted clay liners $(C C L s)$ " are used in waste containment facilities as hydraulic barriers to prevent the flow of liquids (Benson et al. 1994). The performance of a liner ultimately depends on its effectiveness to provide a low enough hydraulic conductivity $(K)$, which European regulatory agencies set to a value less or equal to $1 \times 10^{-9} \mathrm{~m} / \mathrm{s}$ for hazardous and non-hazardous waste (European Union 1999). Strong resistance to chemical attack is also a desirable property of a liner (Koch 2002), because CCLs may be attacked by the chemical wastes or leachates they are meant to contain (Broderick and Daniel 1990). 
Infiltration of hazardous liquids through waste containment barriers can exert contamination and considerable alterations in the geotechnical and hydraulic properties of the liner. Consequently, numerous research works have investigated the effects of organic (e.g. Foreman and Daniel 1986; Bowders and Daniel 1987; Arasan 2010; Mosavat and Nalbantoglu 2011, 2013; Benson et al. 2015) and inorganic liquids (Peterson and Gee 1985; Yilmaz et al. 2008; Malusis and McKeehan 2013) on CCLs, evidencing that organic compounds can destroy the sealing properties of CCLs as a result of the combination of particle flocculation, cracking, reduced double-layer thickness, and desiccation (Broderick and Daniel 1990), whereas inorganic liquids increase $K$ due to changes in the valence of the cation and the electrolyte concentration (Stern and Shackelford 1998; Shackelford et al. 2000; Jo et al. 2004, 2005; Lee et al. 2005). Also, acids and bases can attack CCLs, causing its dissolution and increase in $K$ due to the formation of channels (Bowders et al. 1986; Daniel 1993; Benson et al. 2010; Liu et al. 2013). Therefore, the effect of chemicals is a major concern in determining the performance of CCLs for waste impoundments (Meegoda and Rajapakse 1993).

Liners commonly are constructed with compacted natural clayey soils, clays, or commercially available bentonites and/or a geomembrane, because of their geotechnical properties and low $K$ (Benson and Othman 1993; Taha and Kabir 2005). Despite the adequate performance of such materials, some alternative residual materials_fulfilling some minimum requirements (Daniel 1993)_are receiving increasing attention as potential substitutes for natural clays in liners because of cost reasons, limited availability, conservation of natural clay resources, or poor resistance to chemical attack. Examples of these alternative materials (used alone or as admixture) are steel slags (Andreas et al. 2014), fly ash (Nhan et al. 1996; Hettiaratchi et al. 1999; Sivapullaiah and Lakshmikantha 2004), bottom ash (Kumar and Stewart 2003), cement kiln dust (Amadi and Eberemu 2013), and also red mud (Rubinos et al. 2015).

Red mud (RM) is the solid residue of alumina extraction using the Bayer chemical industrial method, where ground bauxite is digested in a hot $\mathrm{NaOH}\left(250{ }^{\circ} \mathrm{C}\right)$ at high pressure $\left(52 \mathrm{~kg} / \mathrm{cm}^{2}\right) . \mathrm{RM}$ is a highly alkaline $(\mathrm{pH}>10)$ and fine material (90\% of particles less than $75 \mu \mathrm{m}$ ) (Liu et al. 2011), consisting primarily of $\mathrm{Al}, \mathrm{Fe}$, and Ti oxides, silica, calcium oxide, carbonates, and residual alkali. RM also contains some heavy metals and metalloids as impurities, normally in poorly mobile forms (Mayes et al. 2011; Rubinos and Barral 2013). Since $\sim 2.5$ to $3.0 \mathrm{~kg}$ of RM is generated per kg of primary Al produced (Hammond et al. 2013), an enormous amount of RM is produced worldwide $[\sim 120$ million tonnes per year, global inventory $>2.7 \mathrm{Bt}$
(Klauber et al. 2011)], mostly disposed in large landfills. Consequently, efforts have been made to beneficially use $\mathrm{RM}$ in very diverse applications, from its use in industrial chemical processes (e.g. catalyst, adsorbent, polymer, pigments) to its use in construction and civil engineering applications (Klauber et al. 2011).

Due to its geotechnical and adsorptive properties of a wide array of contaminants (Wang et al. 2008; Bhatnagar et al. 2011), RM has been proposed as a liner material (Kalkan 2006; Çoruh and Ergun 2010; Rubinos et al. 2015). However, the chemical compatibility of RM liners (RMLs) has not been previously studied even though rarely the RML would be exposed merely to water when performing as a hydraulic barrier in actual engineering applications. For these reason, a comprehensive study of the compatibility of RMLs and some potential harmful liquids is needed, in order to determine whether RMLs would suffer upon exposure to waste chemicals. Also, the undesirable potential release of RM's hazardous metals as the liquids interact with the RML requires careful evaluation to assure safe use of RM. Hence, a series of laboratory experiments was performed to assess the (1) geotechnical and hydraulic performance of the RML upon exposure to representative organic and inorganic chemical solutions, (2) integrity of the RML when exposed to different-type chemicals, and (3) the potential leaching of RM's major and trace metals when permeated with the chemicals (environmental compatibility), as related to risk due to their toxicity.

\section{Materials and methods}

\section{Red mud}

The RM used in this study was obtained from ALCOA-San Cibrao bauxite refinery (Lugo, Northwest Spain), where it was sampled as an alkaline $(\mathrm{pH} \sim 10.2)$ suspension ( $\sim 47 \%$ water content). RM was merely air-dried (21 days at room temperature), crushed using a hammer mill crusher, and homogenised before use to preserve its original properties and to avoid complex and/or expensive pretreatments. The primary physical, chemical, and geotechnical properties of the RM are summarised in Table 1 . The RM contains $\sim 92 \%$ fines $(\varnothing<75 \mu \mathrm{m})$, whereas the silt $(50 \%)$ and clay $(40 \%)$ fractions predominate. Chemical analyses revealed $\mathrm{Fe}, \mathrm{Ti}$, and $\mathrm{Al}$ oxides accounted for the $70 \%$ of total RM constituents, which also contains several trace metals and metalloids (in the $\mathrm{mg} / \mathrm{kg}$ level) (Table 1). Main minerals (X-ray powder diffraction) were hematite$\left(\alpha-\mathrm{Fe}_{2} \mathrm{O}_{3}\right)$, rutile- $\left(\mathrm{TiO}_{2}\right)$, magnetite- $\left(\mathrm{Fe}_{3} \mathrm{O}_{4}\right)$, boehmite$\left(\gamma\right.$-AlOOH), ilmenite- $\left(\mathrm{FeTiO}_{3}\right)$, and zeolite-type (sodalite, $\mathrm{Na}_{4} \mathrm{Al}_{3} \mathrm{Si}_{3} \mathrm{O}_{12} \mathrm{Cl}$ ) minerals. 


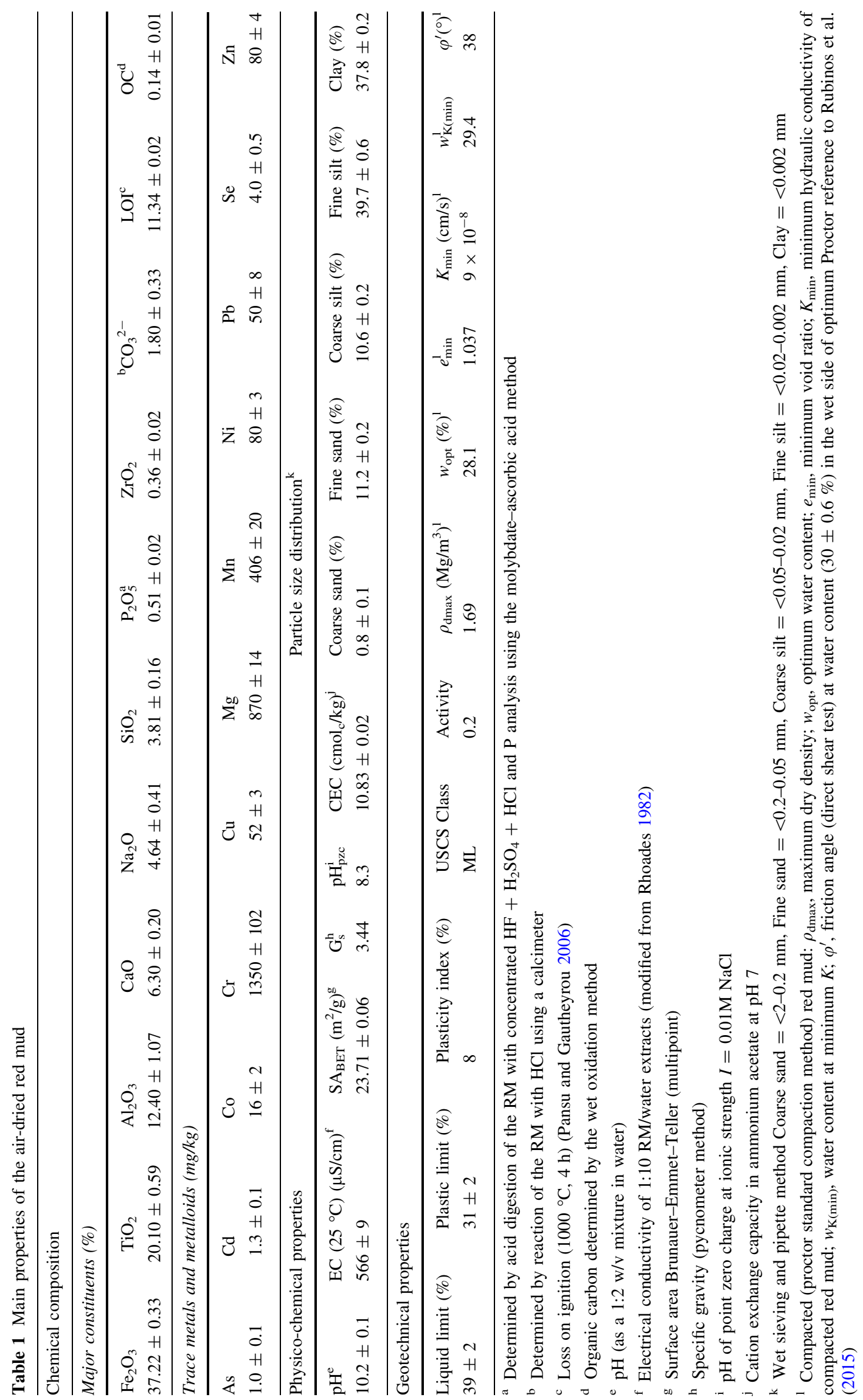




\section{Chemicals tested}

The compounds used were particularly aggressive organic and inorganic chemicals, covering a wide range of physical and chemical properties. The organic chemicals tested were: methanol (neutral polar, dielectric constant $\varepsilon=34$ ), acetic acid (organic acid, $\varepsilon=6$ ), $n$-heptane (neutral nonpolar, $\varepsilon=2$ ), and trichloroethylene (TCE) (chlorinated, $\varepsilon=3$ ). Aqueous solutions of $\mathrm{CaCl}_{2}$ were tested to represent inorganic salt solutions. Additionally, seawater was also tested in the hydraulic conductivity tests only. Deionised (DI) (MilliQ, $18 \mathrm{M} \Omega / \mathrm{cm}$ resistivity) water $(\varepsilon \sim 80)$ was used as reference liquid throughout all tests (Lee et al. 2005; Benson et al. 2015). These compounds have been frequently used in compatibility studies of CCLs (Foreman and Daniel 1986; Bowders and Daniel 1987; Olgun and Yildiz 2010; Benson et al. 2015) to represent different types of chemicals found in waste disposal units: neutral polar industrial solvents (methanol), waste oils and some industrial solvents ( $n$-heptane), and recalcitrant hazardous chlorinated organic chemicals (TCE). Acetic acid was used to represent the organic acids fraction in waste landfill leachates (Öman and Hynning 1993), and it is also used as leaching agent in the US EPA TCLP procedure (Halim et al. 2004). $\mathrm{Ca}^{2+}$ is a ubiquitous contaminant that has been identified as one of the more damaging chemical species of landfill leachates for sodium CCLs (Hettiaratchi et al. 1988; Jo et al. 2005).

\section{Compatibility tests}

\section{Index tests}

The index tests performed were Atterberg limits and sedimentation tests. Methanol and acetic acid were tested at aqueous concentrations of 0 (pure water), 20, 40, 60, 80, and $100 \%$ (pure reagent) by volume. Heptane and TCE were tested at their respective solubility limits in water (53 and $1100 \mathrm{mg} / \mathrm{L}$, respectively) and in its pure form. $\mathrm{CaCl}_{2}$ was tested at $5 \% \mathrm{w} / \mathrm{v}$ aqueous solutions, prepared by dissolving powdered $\mathrm{CaCl}_{2} \cdot 2 \mathrm{H}_{2} \mathrm{O}$ PA-ACS reagent (Panreac, Barcelona) in DI water.

Atterberg limits, i.e. the liquid limit, LL, the plastic limit, PL, and the plasticity index, PI, were determined according to ASTM D4318 specifications, but using the different chemicals as the liquids instead of water. The mixtures were allowed to equilibrate for about $24 \mathrm{~h}$ prior to testing, excepting for the pure organics, for which the tests were performed immediately after thoroughly mixed with the RM, due to their rapid evaporation and effect on RM. Sedimentation tests were carried out through a modification of the procedure described by Bowders et al. (1986), which in turn is based on the ASTM D422 method, but the turbidity of the RM suspensions was measured as a function of time instead the distance from the top of the liquid to the front of the solid-liquid suspension (Supplementary material).

\section{Scanning electron microscopy (SEM)}

RM samples were exposed to pure acetic acid, TCE, and DI water by gentle orbital shaking of RM-chemical suspensions (50 g/L) during 1 week, and then the suspensions were decanted, air-dried and studied by SEM using a LEO 435 - VP variable-pressure unit (Leica Microsystems, Cambridge) operating at $20-\mathrm{kV}$ accelerating voltage.

\section{Hydraulic conductivity tests}

A series of RM specimens were prepared by mixing the pulverised RM with distilled water ( $24 \mathrm{~h}$ of equilibrium) to water contents slightly ( $\sim 0.5$ to $2 \%$ ) wet of optimum standard Proctor ( $w_{\text {opt }}=28.1 \%$ ), where compacted RM is at its minimum $K$ (Rubinos et al. 2015). Then, the resulting wetted RM mixture was compacted using the standard Proctor (ASTM D698) compaction method, from which undisturbed core specimens of known dry density and water content (Table 2) were obtained and sequentially permeated, firstly with water until steady values of $K$, then with each corresponding chemical, using a rigid-wall, falling-head, permeameter. Details of the used apparatus and procedure are described in Supplementary material. The results obtained were expressed in terms of the 'intrinsic permeability, $k^{\prime}$ (in length ${ }^{2}$ ) (Eq. 1) (USEPA 1988):

$k=\frac{K \mu}{\rho g}$

where $\rho$ is the density of the permeant fluid $\left(\mathrm{g} / \mathrm{cm}^{3}\right), \mu$ is the dynamic viscosity of the fluid $(\mathrm{g} /(\mathrm{cm} \mathrm{s}))$, and $g$ is the gravitational constant $\left(\mathrm{cm} / \mathrm{s}^{2}\right)$.

A compromise between reliability and practicality was adopted to terminate hydraulic conductivity tests to allow a practical assessment of the $K$ as accurate as possible within a reasonably testing period (less than $\sim 6$ months). Corresponding tests were conducted until (1) steady-state flow was observed, (2) three or more consecutive readings yielded same (within $25 \%$ of the mean) values of $k$ and (3) at least two pore volume of liquid passed through the RM specimen (Aldaeef and Rayhani 2014; Benson et al. 2015). Additionally, the attainment of a chemical equilibrium state is a desirable condition (as recommended in ASTM D7100), and this was also assessed by measuring influent/effluent electrical conductivity EC and total organic carbon TOC ratios (final ratio values within $1.00 \pm 0.15$ Shackelford et al. 2010), which are practical and reliable indicators to compare chemical composition of either 
Table 2 Properties of the red mud specimens used in the permeability tests

\begin{tabular}{lllll}
\hline Specimen & Permeant $^{\mathrm{a}}$ & $\begin{array}{l}\text { Dry density, } \rho_{\mathrm{d}} \\
\left(\mathrm{Mg} / \mathrm{m}^{3}\right)\end{array}$ & $\begin{array}{l}\text { Water content, } \\
w(\%)\end{array}$ & Void ratio, $e$ \\
\hline 1 & Methanol (0-80 \% v/v) & 1.61 & 29.0 & 1.1 \\
2 & Acetic acid (0-40 \% v/v) & 1.68 & 28.9 & 1.1 \\
3 & Acetic acid (pH 4, pH 2) & 1.60 & 30.0 & 1.2 \\
4 & Heptane (53 mg/L) & 1.62 & 28.9 & 1.1 \\
5 & Heptane (Pure) & 1.55 & 29.3 & 1.2 \\
6 & TCE (1100 mg/L) & 1.57 & 29.2 & 1.2 \\
7 & TCE (Pure) & 1.56 & 29.4 & 1.2 \\
8 & CaCl $(1-5 \% \mathrm{w} / \mathrm{v})$ & 1.65 & 29.8 & 1.1 \\
9 & Seawater & 1.69 & 28.5 & 1.0 \\
\hline
\end{tabular}

${ }^{a}$ All red mud specimens were firstly permeated with DI water electrolyte (Shackelford et al. 2000) or organic solutions (Bowders and Daniel 1987). Attending to such criteria, the tests lasted between 63 and 162 days. Hence, the results must be regarded as "short-term" $k$ of the RML, whereas the experimental conditions may be considered as representative of a worst-case scenario for a CCL.

\section{Environmental compatibility: effluent characteristics}

The effluents from the permeated specimens were periodically sampled, filtered (Whatman ${ }^{\mathrm{TM}} 40$ filters, GE Healthcare, Barcelona), and analysed for $\mathrm{pH}$, electrical conductivity (EC) at $25{ }^{\circ} \mathrm{C}$, suspension solids (by spectrophotometric reading at $370 \mathrm{~nm}$ ), turbidity, and major ( $\mathrm{Fe}, \mathrm{Al}, \mathrm{Ti}, \mathrm{Si})$ and trace $(\mathrm{Cr}, \mathrm{Cd}, \mathrm{Mn}$, and $\mathrm{Ni}$ ) metals of RM (with the exception of methanol effluents). Dissolved metals were analysed by atomic absorption spectrophotometry (AAS) (PerkinElmer 2100 spectrophotometer) or graphite furnace (GF)-AAS (PerkinElmer HGA700). Special attention was paid to $\mathrm{Al}$ and $\mathrm{Cr}$ leaching, which have been reported to be of particular concern due to their relatively high concentrations in RM and their potential mobility under acidic conditions (Milačič et al. 2012; Rubinos and Barral 2013). Selected organic effluents were analysed for TOC using a Shimadzu 5000A analyser (Shimadzu Co., Kyoto).

\section{Results and discussion}

\section{Index tests}

\section{Atterberg limits}

The results obtained for Atterberg limits for all the fluid/ RM combinations tested are summarised in Tables 3 and 4. Methanol at concentrations below $80 \%$ did not significantly affect the LL and PL values of RM comparing to water, whereas for concentrations $\geq 80 \%$ a significant decrease in the LL and in the PI ( $\sim 7$-fold) was observed (Table 3). Pure methanol $(100 \%)$ caused a $\sim 20 \%$ decrease in the LL, and it induced a "non-plastic" state in the RM, which exhibited a granular texture, impossible to be rolled. Overall, a decreasing trend of the plasticity of the RM with the increasing methanol concentration may be inferred. These results suggest a strong influence of methanol on the geotechnical and hydraulic properties of $\mathrm{RM}$ at concentrations $\geq 80 \%$, with drastic effects particularly when RM interacts with the pure alcohol. Similar effects of methanol on consistency limits have been reported for clays as kaolinite and illite-chlorite (Bowders and Daniel 1987); such effects are being attributed to the flocculation and aggregation of the particles when mixed with concentrated methanol solutions of low $\varepsilon(\leq 43)$ which collapse the diffuse double layer and increase the attractive forces between the solid particles.

A significant reduction in both the LL and PL values in acetic acid solutions relative to water occurred (Table 3). Although the LL and PL in acetic solutions showed little variation with the acid concentration, concomitant reduction in LL and increase in PL at acetic acid concentrations $>40 \%$ resulted in a significant decrease (2-3-fold) in the PI compared with that in water. The pure acid caused a further reduction in both the $\mathrm{LL}(\sim 17 \%)$ and $\mathrm{PL}$ ( $\sim 27 \%$ ), but the plasticity of the RM was not suppressed. The more complex effect of acetic acid on consistency limits of RM is probably related with dissolution and dispersion processes of the RM as it reacts with the acid, as discussed subsequently.

Both pure $n$-heptane and TCE strongly affected the Atterberg limits of RM (Table 4), which quickly acquired a granular texture deprived of plasticity, suggesting a great detrimental effect of such chemicals on the RML. As for pure methanol, this fact is related with aggregation processes of the RM particles due to the extremely low $\varepsilon$ of these pure chemicals. Regarding the LL, pure heptane 
Table 3 Atterberg limits of the red mud mixed with methanol and acetic acid solutions

\begin{tabular}{|c|c|c|c|c|c|c|c|c|c|}
\hline \multirow{3}{*}{$\begin{array}{l}\text { Concentration of liquid in water } \\
(\% \mathrm{v} / \mathrm{v})\end{array}$} & \multirow{3}{*}{$\begin{array}{l}\text { Atterberg } \\
\text { limits } \\
(\%)\end{array}$} & \multicolumn{2}{|l|}{ Liquid } & \multicolumn{6}{|l|}{ Parameter } \\
\hline & & \multirow[b]{2}{*}{ Methanol } & \multirow[b]{2}{*}{$\begin{array}{l}\text { Acetic } \\
\text { acid }\end{array}$} & \multicolumn{2}{|l|}{$\overline{\varepsilon^{*}}$} & \multicolumn{2}{|l|}{$\rho\left(\mathrm{g} / \mathrm{cm}^{3}\right)$} & \multicolumn{2}{|l|}{$\mu(\mathrm{cp})$} \\
\hline & & & & Methanol & $\begin{array}{l}\text { Acetic } \\
\text { acid }\end{array}$ & Methanol & $\begin{array}{l}\text { Acetic } \\
\text { acid }\end{array}$ & Methanol & $\begin{array}{l}\text { Acetic } \\
\text { acid }\end{array}$ \\
\hline \multirow[t]{3}{*}{0 (DI water) } & LL & $37.7(0.1)^{\mathrm{a}}$ & $37.7(0.1)^{\mathrm{a}}$ & 80 & 80 & 1.00 & 1.00 & 0.91 & 0.91 \\
\hline & PL & $30.1(1.1)^{\mathrm{a}}$ & $30.1(1.1)^{\mathrm{a}}$ & & & & & & \\
\hline & PI & $7.6(1.2)^{\mathrm{a}}$ & $7.6(1.2)^{\mathrm{a}}$ & & & & & & \\
\hline \multirow[t]{3}{*}{20} & LL & $38.6(0.1)^{\mathrm{b}}$ & $31.0(0.4)^{\mathrm{b}}$ & 71 & 65 & 0.97 & 1.03 & 1.36 & 1.02 \\
\hline & PL & $31.7(0.6)^{\mathrm{a}}$ & $24.0(0.9)^{\mathrm{b}}$ & & & & & & \\
\hline & PI & $6.9(0.7)^{\mathrm{a}}$ & $7.0(0.5)^{\mathrm{a}}$ & & & & & & \\
\hline \multirow[t]{3}{*}{40} & LL & $38.0(0.3)^{\mathrm{a}}$ & $31.2(0.5)^{\mathrm{b}}$ & 62 & 51 & 0.95 & 1.05 & 1.61 & 1.03 \\
\hline & PL & $32.9(0.4)^{\mathrm{a}}$ & $24.9(0.3)^{\mathrm{b}}$ & & & & & & \\
\hline & PI & $5.1(0.5)^{\mathrm{a}}$ & $6.3(0.7)^{\mathrm{a}}$ & & & & & & \\
\hline \multirow[t]{3}{*}{60} & LL & $37.3(0.7)^{\mathrm{a}}$ & $28.5(0.4)^{\mathrm{c}}$ & 52 & 36 & 0.91 & 1.06 & 1.49 & 1.08 \\
\hline & PL & $32.5(1.1)^{\mathrm{a}}$ & $25.7(0.8)^{\mathrm{b}}$ & & & & & & \\
\hline & PI & $4.8(0.9)^{\mathrm{a}}$ & $2.4(0.0)^{\mathrm{b}}$ & & & & & & \\
\hline \multirow[t]{3}{*}{80} & LL & $34.8(0.0)^{\mathrm{c}}$ & $32.3(0.9)^{\mathrm{b}}$ & 43 & 21 & 0.86 & 1.07 & 1.15 & 1.05 \\
\hline & PL & $33.6(0.1)^{\mathrm{a}}$ & $29.1(1.1)^{\mathrm{a}}$ & & & & & & \\
\hline & PI & $1.1(0.2)^{\mathrm{b}}$ & $3.2(1.0)^{\mathrm{b}}$ & & & & & & \\
\hline \multirow[t]{3}{*}{100} & LL & $30.6(0.3)^{\mathrm{d}}$ & $31.3(0.9)^{\mathrm{b}}$ & 34 & 6 & 0.79 & 1.05 & 0.54 & 1.28 \\
\hline & PL & $\mathrm{NP}$ & $27.6(0.5)^{\mathrm{a}}$ & & & & & & \\
\hline & PI & NP & $3.7(1.0)^{\mathrm{b}}$ & & & & & & \\
\hline
\end{tabular}

Values in parentheses indicate standard deviation from the mean of three replicates. Different superscript letters indicate significant differences (one-way ANOVA) at $p<0.05$. Physical properties of methanol and acetic acid solutions are also showed

$N P$ non-plastic

$\varepsilon$, dielectric constant; $\rho$, density at $20{ }^{\circ} \mathrm{C} ; \mu$, absolute viscosity at $20{ }^{\circ} \mathrm{C}$

* Data from Bowders and Daniel (1987)

Table 4 Atterberg limits of the red mud mixed with heptane, TCE and $\mathrm{CaCl}_{2}$

\begin{tabular}{|c|c|c|c|c|c|c|c|c|c|c|c|c|c|}
\hline \multirow{3}{*}{$\begin{array}{l}\text { Concentration } \\
\text { of chemical }\end{array}$} & \multirow{3}{*}{$\begin{array}{l}\text { Atterberg } \\
\text { limits } \\
(\%)\end{array}$} & \multirow{2}{*}{\multicolumn{3}{|c|}{ Compound }} & \multicolumn{9}{|c|}{ Parameter } \\
\hline & & & & & \multicolumn{3}{|l|}{$\varepsilon^{*}$} & \multicolumn{3}{|c|}{$\rho\left(\mathrm{g} / \mathrm{cm}^{3}\right)$} & \multicolumn{3}{|l|}{$\mu$ (ср) } \\
\hline & & Heptane & TCE & $\mathrm{CaCl}_{2}$ & Heptane & TCE & $\mathrm{CaCl}_{2}$ & Heptane & TCE & $\mathrm{CaCl}_{2}$ & Heptane & TCE & $\mathrm{CaCl}_{2}$ \\
\hline \multirow[t]{3}{*}{ Pure } & LL & $33.9(0.1)^{\mathrm{b}}$ & $66.7(1.9)^{\mathrm{b}}$ & & 1.9 & 3.4 & & 0.68 & 1.48 & & 0.41 & 0.58 & \\
\hline & PL & $\mathrm{NP}^{\mathrm{b}}$ & $\mathrm{NP}^{\mathrm{b}}$ & & & & & & & & & & \\
\hline & PI & $\mathrm{NP}^{\mathrm{b}}$ & $\mathrm{NP}^{\mathrm{b}}$ & & & & & & & & & & \\
\hline \multirow{3}{*}{$\begin{array}{l}\text { Solubility } \\
\text { limit }^{\dagger}\end{array}$} & LL & $36.2(0.2)^{\mathrm{a}}$ & $36.3(0.4)^{\mathrm{a}}$ & & 80 & 80 & & 1.00 & 1.00 & & 0.92 & 0.92 & \\
\hline & PL & $32.0(0.6)^{\mathrm{a}}$ & $31.3(0.3)^{\mathrm{a}}$ & & & & & & & & & & \\
\hline & PI & $4.2(0.4)^{\mathrm{a}}$ & $5.0(0.1)^{\mathrm{a}}$ & & & & & & & & & & \\
\hline \multirow[t]{3}{*}{$5 \%(\mathrm{w} / \mathrm{v})$} & LL & & & $37.5(0.2)^{\mathrm{a}}$ & & & & & & 1.04 & & & 0.92 \\
\hline & PL & & & $30.3(0.8)^{\mathrm{a}}$ & & & & & & & & & \\
\hline & PI & & & $7.2(1.0)^{\mathrm{a}}$ & & & & & & & & & \\
\hline
\end{tabular}

Values in parentheses indicate standard deviation from the mean of three replicates. Different superscript letters mean significant differences (oneway ANOVA) at $p<0.05$ with the values for water showed in Table 3. Physical properties of the tested liquids are also showed

$N P$, non-plastic

$\varepsilon$, dielectric constant; $\rho$, density at $20{ }^{\circ} \mathrm{C} ; \mu$, absolute viscosity at $20{ }^{\circ} \mathrm{C}$

* Data from Bowders and Daniel (1987)

${ }^{\dagger}$ Solubility limit: Heptane $=53 \mathrm{mg} / \mathrm{L}, \mathrm{TCE}=1100 \mathrm{mg} / \mathrm{L}$ 
slightly decreased (by $\sim 0.1$-fold) the LL of RM, whereas pure TCE largely increased the LL (by $\sim 1.8$-fold). A similar behaviour has been previously described for an illite/chlorite soil when mixed with either pure TCE or $n$ heptane, and for kaolinite-TCE mixtures (Bowders and Daniel 1987). Even if the LL in TCE was corrected for the density of the pure TCE and expressed as "equivalent LL" (defined as the ratio between the percentage of fluid by weight and the specific gravity of the fluid (Di Matteo et al. 2011) the calculated value $\left(\mathrm{LL}_{\mathrm{eq}}=45.1 \%\right)$ was still higher than the LL in water of the RM. Furthermore, viscosity of pure TCE is lower than that of water (Table 4), which theoretically would contribute to decrease in the LL value by decreasing the resistance and facilitating body motion (Meegoda and Ratnaweera 1994). Therefore, the increase in the LL of RM/TCE mixture cannot be explained by variations in the density-viscosity of the pore fluid, but likely is related with the strong decrease in $\varepsilon$ that enhances inter-particle attractive forces and aggregation of RM, as evidenced by SEM (Fig. 2), thus increasing its shearing resistance and the LL, in a similar manner to as described for kaolinite (Sridharan and Rao 1975). In contrast to pure organics, neither heptane- nor TCE-saturated aqueous solutions changed Atterberg limits of the RM (Table 4). Similarly, the replacement of water by a $5 \%$ (w/v) $\mathrm{CaCl}_{2}$ solution did not significantly alter the plasticity of the RM (Table 4), likely because the displacement of $\mathrm{Na}^{+}$from RM by exchange with $\mathrm{Ca}^{2+}$ ions is a slow and difficult process since a great part of $\mathrm{Na}^{+}$in $\mathrm{RM}$ is not readily accessible (Wong and Ho 1995).

\section{Sedimentation tests}

The results obtained for the sedimentation tests are shown in the Fig. 1. As a general rule, concentrated chemical solutions (low dielectric constant) enhanced settlement of RM particles, while all pure organic chemicals caused a rapid (within the first $15 \mathrm{~min}$ ) sedimentation of RM, which is in accordance with the observed strong effects on the plasticity. Nevertheless, the sedimentation behaviour of the RM differed for the tested chemicals.

In the case of methanol, concentrations between 20 and $60 \%$ by volume enhanced sedimentation of RM at shorter times (below $\sim 100$ to $200 \mathrm{~min}$ ), slowing down hereinafter. Sedimentation was even slower than in water at longer times (Fig. 1b). Since the $\mathrm{pH}$ of the RM/methanol suspensions remained essentially constant at $\mathrm{pH} \sim 10.4 \pm 0.4$, this behaviour could be related with the measured excess viscosity of the more diluted methanol solutions (Table 3). It is well-known that methanol-water binary mixtures deviate from an ideal behaviour of viscosity, exhibiting excess viscosities (with maxima at $\sim 0.25$ methanol mole fraction) as a consequence of the strong intermolecular interactions between these liquids (Kubota et al. 1979; Yilmaz 2002). Accordingly to Stokes' law (Eq. 2) (Mitchell 1993), the velocity of sedimentation, $v$, decreases as the viscosity $\mu$ of the liquid increases, whereas it increases as the density of the liquid decreases (providing the other parameters remain the same):

$v=\frac{\gamma_{\mathrm{s}}-\gamma_{\mathrm{L}}}{18 \mu} D^{2}$

where $\gamma_{\mathrm{s}}=$ unit weight of the particle, $\gamma_{\mathrm{L}}=$ unit weight of the liquid, $\mu=$ viscosity of the liquid, and $D=$ diameter of the particle (spherical).

Even though the $\gamma_{L}$ and $\varepsilon$ of methanol solutions decreased with the methanol concentration, this is not enough to compensate the high increase in the Stokes' equation denominator due to the increase in $\mu$ (Table 3 ), which in turn would result in a lower sedimentation rate of the finest (clay and colloid size) particles of RM in 20-60\% methanol. In contrast, such behaviour was not observed for $80 \%$ methanol, which is a high enough concentration providing a low dielectric constant $(\varepsilon=43$ ) to overcome the effect of $\mu$ (only slightly higher than for water) (Table 3 ), and to accelerate the sedimentation of RM within all the period studied. As previously indicated, $100 \%$ methanol caused the almost immediate settlement of RM particles due to the low $\varepsilon=34$ of the pure liquid. These results suggest a severe affectation of the RML at concentrations $\geq 80 \%$ methanol, but also potential detrimental effects of more diluted (40-60\%) methanol on the coarser size fractions of RM.

Regarding the acetic acid, 20 and $40 \%$ acetic acid solutions exerted a clear dispersive effect on the RM (Fig. 1c). Conversely, at concentrations $>40 \%$ acetic the sedimentation rate increased with the concentration of acid. The pure acid induced a rapid settlement of RM particles. The observed effect on sedimentation is contributed by several interacting parameters: density $\rho, \mu, \mathrm{pH}$, ionic strength $I$, and $\varepsilon$. The $\rho$ of the acetic solutions slightly varied with the acid concentration $(\rho=0.998-1.05 \mathrm{~g} /$ $\mathrm{cm}^{3}$ ), whereas a noticeable $\mu$ increase was only found for pure acetic acid $(\mu=1.3 \mathrm{cp})$ (Table 3$)$, thus making unlikely the involvement of these parameters. The characteristics of the pore fluid $(\mathrm{pH}$, ion concentration and type, and $\varepsilon$ ) are critical variables controlling the flocculationdispersion behaviour of fine particles (Santamarina et al. 2002). The $\mathrm{pH}$ of the suspensions greatly decreased from $\mathrm{pH} 10.7$ for $\mathrm{RM} /$ water to $\mathrm{pH} 3.0$ for $\mathrm{RM} / 20 \%$ acetic acid suspensions, while it further decreased to $\mathrm{pH} 2.7,2.3,1.7$ and $<1$ as the acid concentration acid increased from 40 to $100 \%$. Since RM exhibits a pH-dependent variable surface charge behaviour with a $\mathrm{pH}_{\mathrm{pzc}}$ (zero proton condition, point of zero charge) at 7.5 for high ionic strength $(I=1 \mathrm{M}$ $\mathrm{NaCl}$ ) (Rubinos 2008)_determined by acidimetric-alkalimetric titration of a RM suspension in the electrolyte 

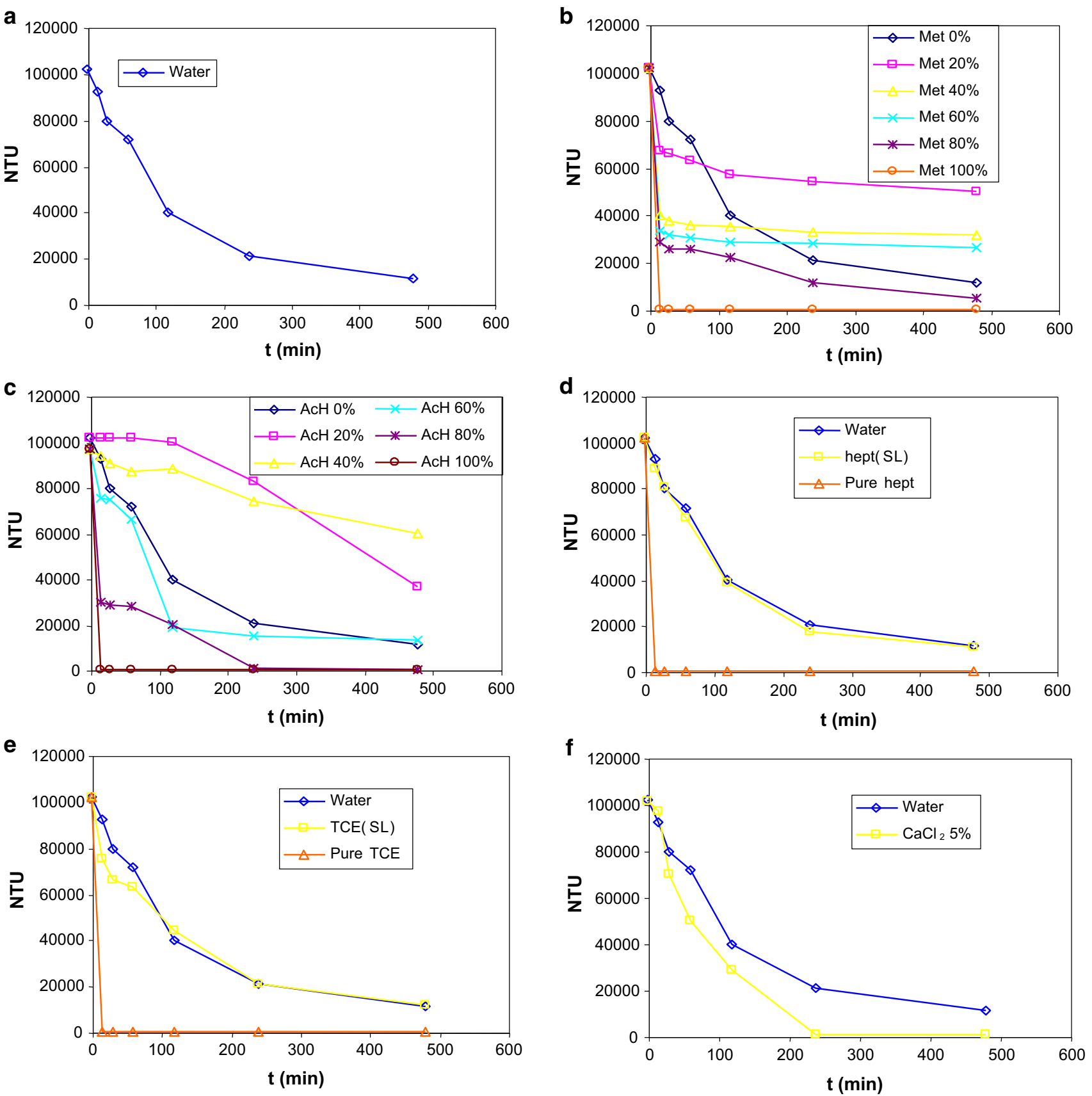

Fig. 1 Sedimentation patterns [residual turbidity (NTU) vs time (minutes)] for red mud (50 g RM/L) suspended in a deionised water, b methanol aqueous solutions (0-100\% by volume), c acetic acid aqueous solutions ( $0-100 \%$ by volume), $\mathbf{d}$ heptane (at its solubility

(Stumm and Morgan 1996)—-the decrease in pH drastically changes the mean surface charge density $\sigma$ of RM particles from predominantly negative in water suspensions $\left(\sigma \sim-3.3 \mathrm{C} / \mathrm{m}^{2}\right.$ at $\left.\mathrm{pH} 10.7\right)$ to positive in the acid suspensions $\left(\sigma \sim 11.8 \mathrm{C} / \mathrm{m}^{2}\right.$ at $\mathrm{pH}$ 3), which enhances interparticle repulsion and induces dispersion. In contrast, with increasing $I$, the attraction is preponderant over larger interparticle distances, the electrical double layer

limit in water $(\mathrm{SL}=53 \mathrm{mg} / \mathrm{L})$ and as pure chemical), e trichloroethylene (TCE) (at its solubility limit in water $(\mathrm{SL}=1,100 \mathrm{mg} / \mathrm{L})$ and as pure chemical, and f $5 \%(\mathrm{w} / \mathrm{v}) \mathrm{CaCl}_{2}$ aqueous solution

compresses, and the particle stability decreases (Stumm and Morgan 1996). Furthermore, RM exhibits a particular behaviour where the surface charge decreases as $I$ increases in the acidic region (Atun and Hisarli 2000; Rubinos 2008) causing the electrostatic repulsion energy decreases as the concentration of acid and $I$ increase, resulting in aggregation of RM particles. Also, $\varepsilon$ of the acetic solutions progressively decreases with the acid concentration from 
$\varepsilon \sim 65(20 \%$ acetic acid) to $\sim 6$ (pure acetic acid) (Table 3), which contributes to such aggregation effect. In addition to these processes, dissolution of some (hydr)oxides of the RM in the extremely acidic acetic solutions takes place, causing the release of high concentrations of $\mathrm{Al}^{3+}$ and $\mathrm{Si}^{4+}$ (Rubinos and Barral 2013), and their contribution cannot be obviated since they induce particle coagulation (Palomino and Santamarina 2005; Spagnoli et al. 2012).

Considering these variables together, there was a "critical threshold" concentration of acetic acid ( $60 \%)$ providing a particular combination of physico-chemical conditions beyond which the overall energy of interaction is attractive and favours aggregation of RM particles. This effect is particularly apparent for RM interacted with pure (very low $\varepsilon$ ) acetic acid, as also directly evidenced by the SEM micrographs clearly showing that the RM acquired a granular aggregated microstructure upon exposure to the pure acid, in comparison with the more disperse and uniform structure of the RM/water system (Fig. 2). Overall, the sedimentation tests suggest a detrimental affectation of the RML properties at acetic acid concentrations $\geq 60 \%$.

Neither $n$-heptane nor TCE at their respective solubility limits induced settlement of RM particles. In contrast, both pure liquids induced an almost immediate sedimentation of RM (Fig. 1d, e), due to their extremely low $\varepsilon$ (Table 4), which causes the aggregation of RM particles. This was confirmed by the SEM observations of RM exposed to pure TCE (Fig. 2) showing an aggregated microstructure of the RM. This suggests that direct exposure to pure organic chemicals would cause drastic effects on the RML properties, with loss of plasticity and intense aggregation of particles, leading to crack development and likely increase in the $K$ of the liner.

Inorganic $5 \% \mathrm{CaCl}_{2}$ moderately enhanced the sedimentation rate at times above $30 \mathrm{~min}$, with the greater differences with water/RM suspensions observed at $t>240$ min (Fig. 1f). $\mathrm{Ca}^{2+}$ may replace at some extent $\mathrm{Na}^{+}$in the exchange sites on RM surfaces, inducing the flocculation of $\mathrm{RM}$ particles. $\mathrm{Ca}^{2+}$ ions destabilize the $\mathrm{Fe}$ (III) oxide colloids by compressing the electric double layer (Stumm and Morgan 1996), which further contributes to enhance sedimentation rate in the presence of $\mathrm{Ca}^{2+}$. Nevertheless, the sedimentation test suggests that $\mathrm{CaCl}_{2}$ solutions exert a less intense effect than organic fluids on RM properties.

\section{Permeability tests}

\section{Permeation with methanol}

A water-saturated specimen of compacted RM was sequentially permeated with $40-80 \% \quad(\mathrm{v} / \mathrm{v})$ aqueous methanol solutions. The permeation lasted $\sim 3.5$ months,

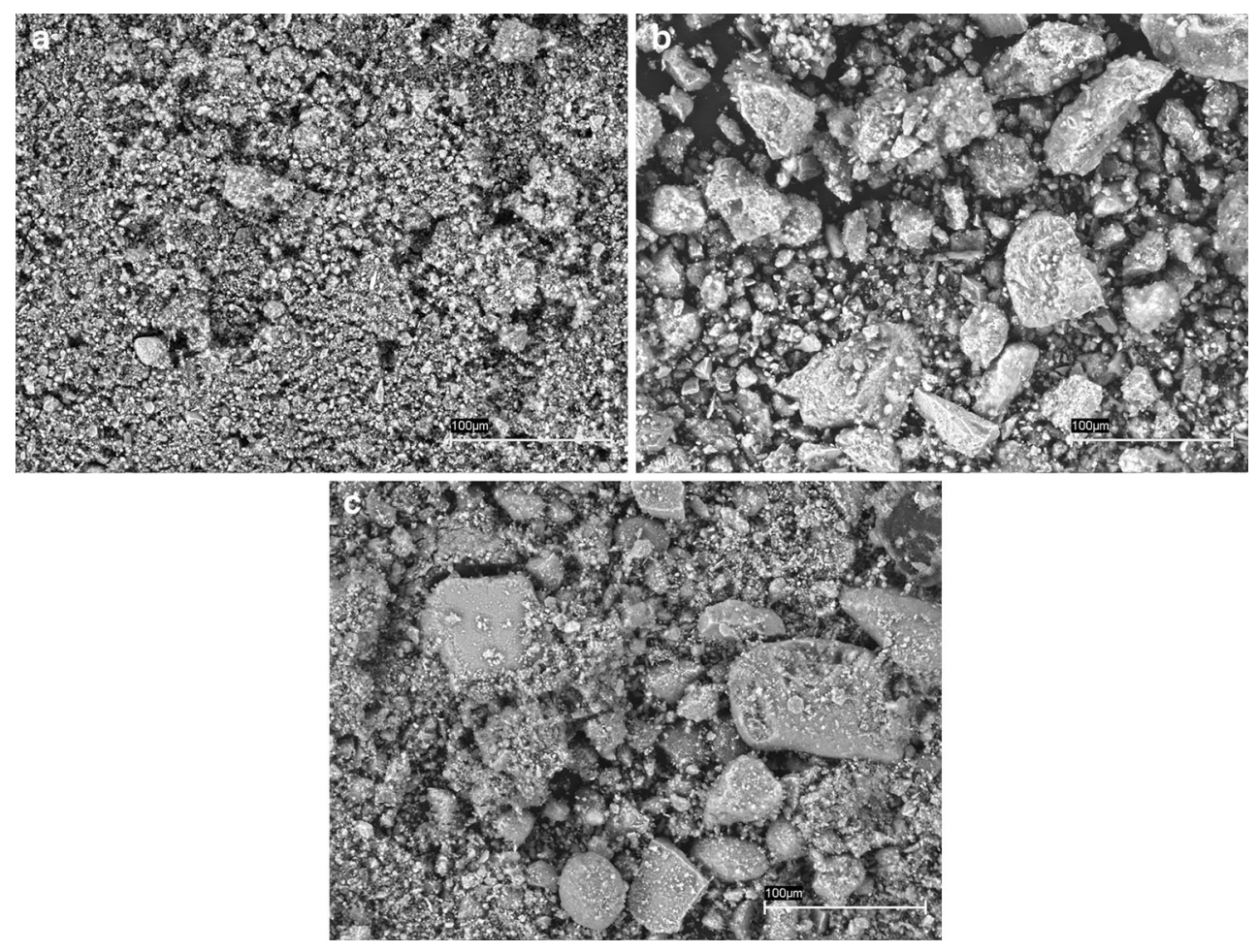

Fig. 2 SEM images of the red mud after exposure (1 week) to a DI water, $\mathbf{b}$ pure acetic acid and $\mathbf{c}$ pure TCE 
Table 5 Summary of permeability results for the red mud permeated with methanol solutions as a function of methanol concentration

\begin{tabular}{llllll}
\hline Concentration of methanol $(\% \mathrm{v} / \mathrm{v})$ & $K_{\mathrm{f}}(\mathrm{cm} / \mathrm{s})$ & $k_{\mathrm{f}}\left(\mathrm{cm}^{2}\right)$ & $\mathrm{PVF}$ & $k_{\mathrm{met}} / k_{\mathrm{w}}$ & $\mathrm{TOC}_{\mathrm{e}} / \mathrm{TOC}_{\mathrm{i}}$ \\
\hline 0 & $1.99 \times 10^{-7}$ & $1.84 \times 10^{-12}$ & 2.9 & & \\
40 & $1.45 \times 10^{-7}$ & $2.51 \times 10^{-12}$ & 6.4 & 1.37 & 0.9 \\
60 & $1.16 \times 10^{-7}$ & $1.96 \times 10^{-12}$ & 9.5 & 1.07 & 0.9 \\
80 & $1.39 \times 10^{-7}$ & $1.88 \times 10^{-12}$ & 12.5 & 1.02 & 0.9 \\
\hline
\end{tabular}

$K_{\mathrm{f}}$, final hydraulic conductivity; $k_{\mathrm{f}}$, final intrinsic permeability; $P V F$, pore volumes permeated; $k_{\mathrm{met}} / k_{\mathrm{w}}$, ratio between intrinsic permeability for methanol solutions and water; $T O C_{\mathrm{e}} / T O C_{\mathrm{i}}$, effluent-to-influent total organic carbon ratio

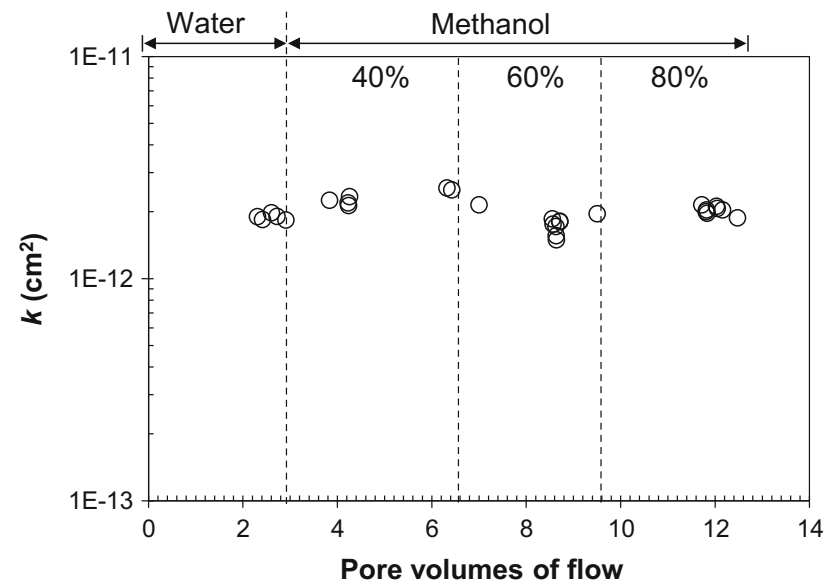

Fig. 3 Intrinsic permeability $k$ versus pore volumes of flow for compacted red mud permeated with $40-80 \% \mathrm{v} / \mathrm{v}$ methanol aqueous solutions

during which $\sim 12.5$ pore volumes of flow (PVF) were percolated. The $K$ was slightly higher to water than to methanol solutions (Table 5), attributed to differences in the $\rho$ and $\mu$ of the liquids. This was supported by the fact that, conversely, merely slight changes in the intrinsic permeability $k$ were observed when methanol solutions were permeated (Fig. 3). Noteworthy, the permeation of RM with $80 \%$ methanol did not adversely affect $k$. Effluent monitoring showed that, despite of final effluent/influent TOC ratios were $<1$, they fell within the assumed permissible variation range $( \pm 0.15)$ of pseudo-equilibrium chemical conditions (Table 5). Also, the effluent EC values quickly decreased from $\mathrm{EC}=5.90 \mathrm{mS} / \mathrm{cm}$ (after percolation of $\sim 3 \mathrm{PVF}$ water) to $\mathrm{EC}=0.60 \mathrm{mS} / \mathrm{cm}$ (after percolation of $\sim 2.5$ PVF $80 \%$ methanol), an EC value close to that measured for a completely mixed RM/80\% methanol $(50 \mathrm{~g} / \mathrm{L})$ suspension $(\mathrm{EC}=0.54 \mathrm{mS} / \mathrm{cm})$, suggesting the full exposure of the RM specimen to the methanol solution.

The absence of detrimental effects on $k$ even for $80 \%$ methanol contrasts with the index tests results. This divergence likely is due to the densification of the RM mass upon compaction, which hinders the soil particles reorientation and the formation of syneresis cracks (Broderick and Daniel 1990). This suggests that compaction of RM improves its chemical resistance and raised the critical threshold effect concentration, pointing to a strong resistance of the RML to methanol.

\section{Permeation with acetic acid}

Permeation of the RML with $20 \%$ acetic acid caused a slight decrease in $k$ from $9.65 \times 10^{-13}$ to $8.00 \times$ $10^{-13} \mathrm{~cm}^{2}$ after 35 days of permeation $(\sim 2.1 \mathrm{PVF})$. When the influent acetic acid concentration was increased to $40 \%$, the flow became erratic and quickly dropped practically to zero, with visible presence of gas in the outflow tube. After two months of exposure of the specimen to the acetic acid, the flow did not increase, thus precluding the specimen was permeated.

A similar effect was observed by Broderick and Daniel (1990) when permeated clayey soils and commercial clays with acetic acid, attributed to the formation of $\mathrm{CO}_{2}$ gas and precipitation of solid matter as the acid was buffered. The occurrence of carbonates $(1.8 \% \mathrm{w} / \mathrm{w})$ in the RM, as also the presence of gas in the outflow, agrees such phenomenon. Besides, the effluent cloudy appearance and reddish colour suggest that the dispersion of RM as percolated with the acetic solutions contributed to reduce the $k$. The analysis of the effluents seemed to confirm it, but also revealed structure loss upon exposure of the RM to such acetic acid concentrations, since the concentration of metals in the effluent (mainly $\mathrm{Si}$ and $\mathrm{Al}$ ) increased upon exposure to the acid (Table 6). Inspection of the RM specimen after acid exposure evidenced surface affectation and occurrence of small cracks, suggesting it could detrimentally affect the long-term hydraulic performance of the RML. In order to assess whether exposure to acetic acid caused irreversible damages on the RML, the specimen was dissembled, air-dried for approximately 40 days and re-permeated with DI water. The $K$ increased ( $\sim 77$-fold) from its initial (pre-acetic) $K=9.47 \times 10^{-8}$ to final (postacetic) $K=7.28 \times 10^{-6} \mathrm{~cm} / \mathrm{s}$, an increase much higher than previously found ( $\sim 6$-fold) for the compacted RM when subjected to merely wet-dry cycling (Rubinos et al. 
Table 6 Characteristics of the effluent from the red mud specimen permeated with 20-40\% acetic acid solutions. Data for re-permeation with water after air-drying of the red mud specimen are also showed

\begin{tabular}{lcccccccc}
\hline Permeant & Days of permeation & $\mathrm{pH}$ & $\mathrm{EC}(\mathrm{mS} / \mathrm{cm})$ & $\mathrm{SS}(\mathrm{mg} / \mathrm{L})$ & $\mathrm{Si}(\mathrm{mg} / \mathrm{L})$ & $\mathrm{Al}(\mathrm{mg} / \mathrm{L})$ & $\mathrm{Fe}(\mu \mathrm{g} / \mathrm{L})$ & $\mathrm{Cr}(\mu \mathrm{g} / \mathrm{L})$ \\
\hline Water & 5 & 9.9 & 9.9 & 29.8 & 1.8 & 5.6 & 110 & 3970 \\
Water & 12 & 9.9 & 6.0 & 8.0 & 1.2 & 6.9 & 100 \\
AcH 20\% & 65 & 8.5 & & 3.2 & 4.4 & 0.3 & 130 \\
AcH 40 \% & 69 & 8.3 & & 3.1 & 5.5 & 0.5 & 290 & 20 \\
Water $^{\mathrm{a}}$ & 1 & 7.6 & 10.7 & 26.8 & 24.0 & 64.4 & 280 & 130 \\
Water $^{\mathrm{a}}$ & 2 & 8.4 & 1.9 & 2.6 & 1.6 & 0.3 & 90 & $\mathrm{ND}^{\mathrm{a}}$ \\
Water $^{\mathrm{a}}$ & 3 & 8.7 & 0.6 & 2.6 & 1.3 & 0.5 & 80 & $\mathrm{ND}$ \\
\hline
\end{tabular}

$N D$, not detected; $E C$, electrical conductivity; $S S$, suspended solids concentration

${ }^{\text {a }}$ Data for re-permeation with water (3 consecutive days of permeation after air-drying of the red mud specimen)

Table 7 Summary of permeability results for the red mud permeated with $\mathrm{pH} 4$ and $\mathrm{pH} 2$ acetic acid solutions

\begin{tabular}{llllll}
\hline Permeant & $K_{\mathrm{f}}(\mathrm{cm} / \mathrm{s})$ & $k_{\mathrm{f}}\left(\mathrm{cm}^{2}\right)$ & $\mathrm{PVF}$ & $k_{\mathrm{AcH}} / k_{\mathrm{w}}$ & $\mathrm{TOC}_{\mathrm{e}} / \mathrm{TOC}_{\mathrm{i}}$ \\
\hline Water & $1.40 \times 10^{-7}$ & $1.29 \times 10^{-12}$ & 2.3 & 1.0 & \\
AcH pH 4 & $1.40 \times 10^{-7}$ & $1.31 \times 10^{-12}$ & 3.1 & 1.0 & \\
AcH pH 2 & $8.35 \times 10^{-8}$ & $7.86 \times 10^{-13}$ & 8.2 & 0.6 & 0.9 \\
Water & $1.07 \times 10^{-7}$ & $9.84 \times 10^{-13}$ & 9.4 & 0.8 & \\
\hline
\end{tabular}

$K_{\mathrm{f}}$, final hydraulic conductivity; $k_{\mathrm{f}}$, final intrinsic permeability; $P V F$, pore volumes permeated; $k_{\mathrm{AcH}} / k_{\mathrm{w}}$, ratio between intrinsic permeability for $\mathrm{pH} 4$ and $\mathrm{pH} 2$ acetic acid solutions and water; $T O C_{\mathrm{e}} / T O C_{\mathrm{i}}$, effluent-to-influent total organic carbon ratio
2015). The combined effect of acid exposure followed by desiccation seems to be particular aggressive and damaging conditions for the RML.

On the other hand, the permeation of acetic acid solutions with $\mathrm{pH} 4$ and $\mathrm{pH} 2$ (pH values frequently found in young landfill and mine waste leachates, respectively) passed without gas production, and a stable flow was attained. Following introduction of the $\mathrm{pH} 4$ solutionused here as a transition permeant $(<1$ PVF $)$ - a slight increase in $k$ was observed, and then it quickly decreased to ca. baseline $k$. Permeation of the $\mathrm{pH} 2$ acetic solution caused a slight and progressive $k$ decrease up to $k \sim 8 \times 10^{-13} \mathrm{~cm}^{2}$ after $\sim 5$ PVF percolated (Fig. 4, Table 7). The final effluent/influent TOC ratio for the $\mathrm{pH} 2$ solution was within the acceptable variation range, suggesting approach to chemical equilibrium. However, as it is inferred from the effluent $\mathrm{pH}$ values, the establishment of a true chemical equilibrium between the acetic acid influent and the RML would require a much longer permeation period than used in this study. Visual inspection after acetic acid exposure did not evidence any sign of damage (i.e. cracks, sidewall contraction, or granular aspect) of the RM specimen, which maintained its homogeneous aspect. Also, the re-permeation of the RML with DI water (up to 162 days, $\sim 9.5 \mathrm{PVF}$ ) caused the $k$ slightly increased again to values close to the baseline $k$. Overall, these results suggest that acetic acid leachates with $\mathrm{pH} \geq 2$ do not cause

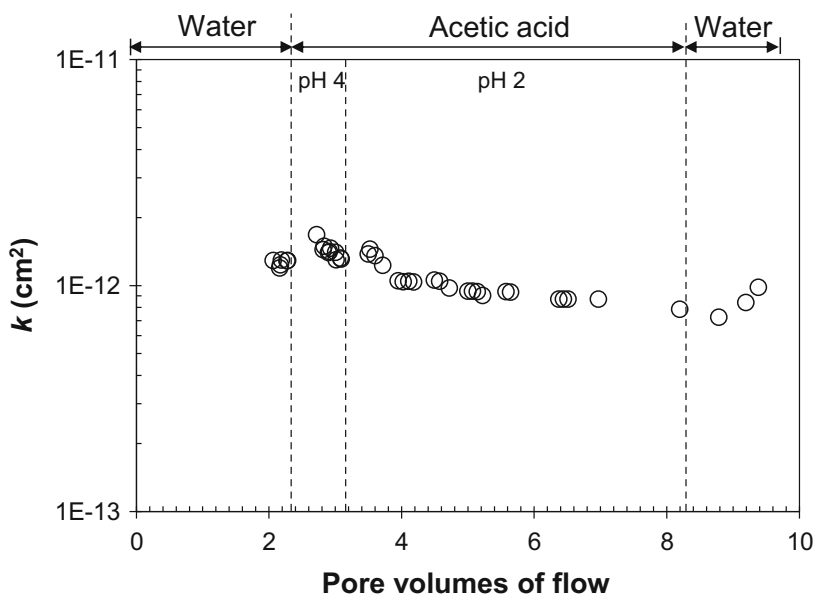

Fig. 4 Intrinsic permeability $k$ versus pore volumes of flow for compacted red mud permeated with $\mathrm{pH} 4$ and $\mathrm{pH} 2$ acetic acid solutions

detrimental effects on the hydraulic performance of the RML, a least in the short time.

Mechanisms of interaction and environmental compatibility with $\mathrm{pH} 4$ and $\mathrm{pH} 2$ acetic acid solutions The effluents from the RML initially presented a reddish colour and turbidity due to the presence of suspended solids (SS), but they quickly (after $\sim 1 \mathrm{PVF}$ ) became clearer, showing that 
the compacted RM is physically stable when permeated with water. The introduction of the $\mathrm{pH} 4$ solution caused the increase in SS concentration and turbidity (Fig. 5a, b), which suggests the occurrence of RM dispersion, and then decrease as the $\mathrm{pH} 2$ solution was percolated. The re-percolation of water did not result in an increase in the SS concentration or turbidity, suggesting that the structure of the RML remained stable after percolation of the acidic solutions.

Electrical conductivity (EC) also decreased from its very high initial value when water was percolated due to the washing of the RM (Fig. 5c), which is characterised by its salt-rich (mainly $\mathrm{Na}$ salts and residual soda) chemical composition. Then, effluent EC progressively increased as the acidic solutions were percolated, to finally decrease again when water was re-introduced through the RM probe. This may be explained attending to the neutralisation of acid as reacting with the RM, a process occurring through the dissolution of its constituents, releasing firstly residual alkali and soluble salts (mainly of $\mathrm{Na}$ and $\mathrm{Ca}$ ) as the acid is buffered (Rubinos and Barral 2013). This results in an enhancement of the leached salt concentration, and hence of the EC, of the effluent, while the $\mathrm{pH}$ is maintained.

The effluent $\mathrm{pH}$ did not change from its initial value for water $(\mathrm{pH} \sim 10)$ when the $\mathrm{pH} 4$ leachate was introduced (Fig. 5d), suggesting a rapid neutralisation of the acid by the $\mathrm{RM}$, while the effluent $\mathrm{pH}$ progressively decreased as the $\mathrm{pH} 2$ solution flowed through the RML. Nevertheless, the effluent $\mathrm{pH}$ did not decrease below 7.9, evidencing a very high acid neutralisation capacity (ANC) of the RM. Besides, effluent $\mathrm{pH}$ increased again (up to $\mathrm{pH} \sim 9$ ) when water was re-introduced, showing that the ANC of the RM specimen was far away from exhaustion at the end of the permeation period. In fact, previous research reported an $\mathrm{ANC}_{\mathrm{pH} 2}=5.5 \mathrm{~mol} \mathrm{H} / \mathrm{kg}$ for the studied $\mathrm{RM}$ and showed that an addition of $\sim 100 \mathrm{~mol}$ acetic acid per $\mathrm{kg}$ RM would be needed to exhaust the buffering capacity of the RM to a final $\mathrm{pH} \sim 2.9$ (Rubinos and Barral 2013). From the environmental point of view, even though alkalinity has been reported as the main concerning environmental risk of RM (Liu et al. 2011; Anton et al. 2012), this is a valuable property in the case of the RML is used to contain acid waste leachates, as their acidity is attenuated as reacting with the RM. Moreover, the high $\mathrm{pH}$ and ANC favour the removal of heavy metals from leachates, which exhibit poor solubility in the alkaline $\mathrm{pH}$ region and hence would be immobilised by precipitation (in addition to adsorption) as hazardous leachates pass through the RML (chemical barrier function).

Buffering of acids by RM has been discussed in detail in previous researches (Wong and Ho 1988; Khaitan et al. 2009), showing that $\mathrm{H}^{+}$neutralisation occurs mostly through reaction with residual alkali, calcium aluminate, and carbonates, but also through dissolution of some structural constituents of RM, primarily aluminosilicates integrating the desilication product (DSP) which suddenly dissolve at $\mathrm{pH}<5.3$ (Rubinos and Barral 2013). Therefore, it is plausible that decrease in "local" $\mathrm{pH}$ at the inflow extreme of the RML causes the dissolution of $\mathrm{Al}$ from DSP, which eventually is prone to precipitate upwards the $\mathrm{RM}$ specimen as the influent is neutralised and the $\mathrm{pH}$ increases, thus clogging the pore voids within the RML and contributing to decrease $k$ as described by Peterson and Gee (1985) and Aldaeef and Rayhani (2014) for CCLs permeated with an acidic $(\mathrm{pH} 2)$ leachate or with slightly acidic synthetic landfill leachate, respectively. Also, dispersion and subsequent internal migration of the clay size particles can block the soil pores of preferential flow and decrease $K$ (Frenkel et al. 1992). The occurrence of particle migration within the RML is supported by the increase in effluent SS concentration and turbidity in response to $\mathrm{pH} 4$ solution introduction, and the subsequent decrease as $\mathrm{pH} 2$ acetic was percolated (Fig. 5e, f). The relatively higher levels of leached $\mathrm{Al}$ in $\mathrm{pH} 4$ than in $\mathrm{pH} 2$ acetic solution suggest the contribution of a (hydr-)oxides dissolution/precipitation mechanism, but this requires further and direct confirmation. However, it is relevant to note that an increase in $k$ could occur in the longterm, once enough acid to exhaust the ANC of the RML is percolated and RM (hydr-)oxides (re-)dissolve. Nevertheless, attending to the total ANC at $\mathrm{pH} 2$ (for a 24-h reaction period) of the RM $\left(\mathrm{ANC}_{24(\mathrm{pH} 2)}=4.8 \mathrm{~mol} \mathrm{H}^{+} / \mathrm{kg}\right) \quad($ Rubinos and Barral 2013), 1425 PVF of acidic pH 2 influent should pass through the RM specimen to overcome the ANC of the 4-cm-thick RML and the effluent $\mathrm{pH}$ equals to the influent $\mathrm{pH} 2$, which correspond to $\sim 40$ years of continuous permeation assuming a constant $K=10^{-7} \mathrm{~cm} / \mathrm{s}$ and low hydraulic gradient, $i \sim 10$. Using the same hydraulic head and $K$, it is estimated that $\sim 30$ years would take a liquid to cross through a 1-m-thick RML, while more than 3000 years should pass to the effluent pH fall to 2 .

Regarding the undesirable release of metals when the RML was permeated with acetic acid leachates, it is worth to mention that the metal concentrations in the first PVF were high, but they quickly decreased. The introduction of the $\mathrm{pH} 4$ solution rose the effluent concentrations of $\mathrm{Al}$ and Si (Fig. 5e, f), but these closely correlated $\left(r^{2}=0.891\right.$ and $r^{2}=0.913$, respectively) with the SS concentration, suggesting that $\mathrm{Al}$ and Si leaching was actually linked to the presence of fine particles in suspension. The concentrations of metals initially decreased when the $\mathrm{pH} 2$ solution was introduced in the RML, and then a progressive increase in the concentrations of $\mathrm{Al}, \mathrm{Si}$, and to a lesser extent of $\mathrm{Fe}$, was observed after the passage of $\sim 3$ PVF of this solution (Fig. 5). This increase followed an inverse relationship with the concentration of SS; conversely, the effluent 

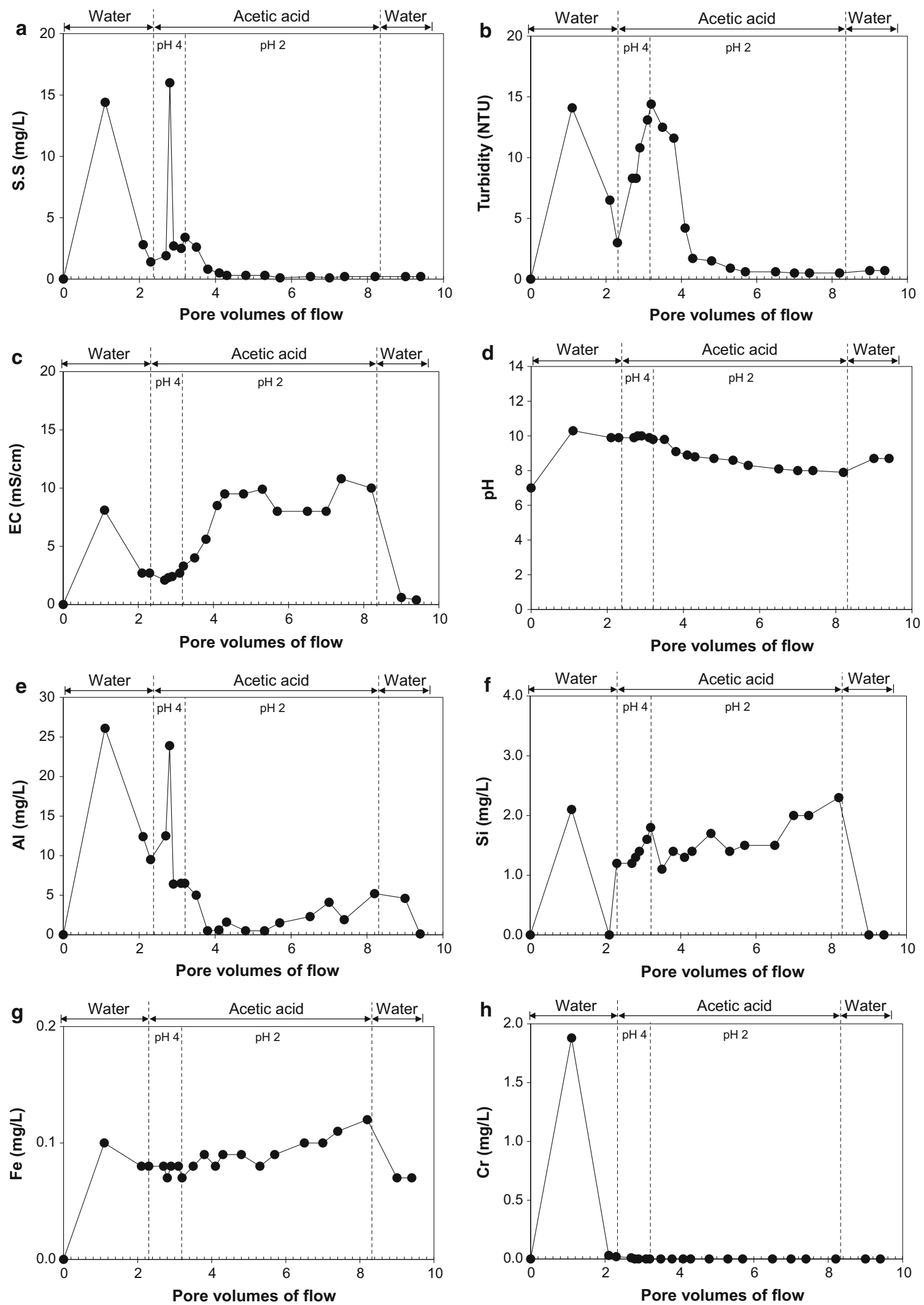

Fig. 5 Characteristics of the effluent from the red mud permeated with $\mathrm{pH} 4$ and $\mathrm{pH} 2$ acetic acid solutions. a Suspended solids (S.S.) concentration, b turbidity, $\mathbf{c}$ electrical conductivity (EC), $\mathbf{d ~ p H}, \mathbf{e ~ A l}, \mathbf{f ~ S i}, \mathbf{g ~ F e}$ and $\mathbf{h} \mathrm{Cr}$ concentrations, as a function of pore volumes of flow 
concentrations of $\mathrm{Al}, \mathrm{Si}$, and $\mathrm{Fe}$ directly correlated $\left(r^{2}=0.895, r^{2}=0.743\right.$ and $r^{2}=0.782$, respectively) with the effluent $\mathrm{H}^{+}$concentration. The released Fe concentrations were very low throughout the complete permeation process and structurally negligible (Fig. $5 \mathrm{~g}$ ). As for effects on the RML structure, these low amounts of dissolved constituents of RM seem to be of minor relevance.

However, from the environmental health point of view, the undesirable release of metals requires evaluation, especially in acidic media. Amongst the major metals in $\mathrm{RM}$, previous studies suggested that $\mathrm{Al}$ release could be concerning (Milačič et al. 2012; Rubinos and Barral 2013) due to the ecotoxicity (Gensemer and Playle 1999) and suspected neurotoxicity of this element (Bondy 2010). The found $\mathrm{Al}$ concentrations in the acetic effluents exceeded the World Health Organisation (WHO) health-based rounded value $(0.9 \mathrm{mg} / \mathrm{L})$, derived from the JECFA provisional tolerable weekly intake (PTWI) (WHO 2011). Maximum $\mathrm{Al}$ concentrations (up to $\sim 29$-fold, the WHO guideline) were found in the "first wash" and $\mathrm{pH} 4$ effluents. Even though $\mathrm{Al}$ in the $\mathrm{RM}$ is largely $(\sim 75 \%)$ in the residual fraction (hence not readily mobile), and the water-soluble $\mathrm{Al}$ accounts only for $0.14 \%$ of total $\mathrm{Al}$ in the RM, high amounts of $\mathrm{Al}(\sim 90 \mathrm{~g} \mathrm{Al}$ per $\mathrm{t} \mathrm{RM})$ could be released as highly mobile water-soluble $\mathrm{Al}$ due to its high concentration in the RM ( $\sim 6.6 \%$ of total constituents) (Rubinos and Barral 2013). With the progressive washing of the RML, effluent $\mathrm{Al}$ concentration notoriously dropped to undetectable levels. Nevertheless, it is advisable to maintain the RML pH above 5.3 and carefully monitor the leachate $\mathrm{Al}$ concentrations when the RML be used to contain acidic (or acid generating) wastes. The effluent concentrations of $\mathrm{Si}$ and particularly $\mathrm{Fe}$ were always below the WHO drinking water standards. This is noteworthy, because poor dissolution of Fe oxides controls and limits the mobility of trace metals in the RM (Rubinos and Barral 2013).

Amongst the trace metals, $\mathrm{Cr}$ requires special attention because of its relatively high concentration in the RM, its enhanced mobilisation from the RM at strongly acidic $\mathrm{pH}$ $(<2)$ (Rubinos and Barral 2013), and the toxicity of its hexavalent oxidation state (Gad 1989). Despite the fact that we did not determine speciation of $\mathrm{Cr}$ in the solid RM, recent studies using synchrotron X-ray absorption spectroscopy revealed that $\mathrm{Cr}$ in $\mathrm{RMs}$ with different origin (Ajka-Hungary and Western Australia) is predominately present as $\mathrm{Cr}^{3+}$, closely associated with iron oxides (primarily hematite) (Gräfe et al. 2011; Burke et al. 2012), which greatly limits the environmental risks. Also, Milačič et al. (2012) reported that water-soluble $\mathrm{Cr}$ is almost exclusively as colloidal $\mathrm{Cr}(\mathrm{OH})_{3}$ species in moderately alkaline RM ( $\mathrm{pH}$ 9) from Kidričevo (Slovenia). In contrast, these authors found toxic aqueous $\mathrm{Cr}^{6+}$ in $\mathrm{RM}$ from $\mathrm{Ajka}$, whose high alkalinity $(\mathrm{pH} \sim 12)$ favours the oxidation of soluble $\mathrm{Cr}$ by air oxygen, suggesting that the presence of this toxic specie should not be neglected at such extreme pHs. Nevertheless, the very low solubility of hematite in the $\mathrm{pH}$ range 2-14 and the very slow kinetics of $\mathrm{Cr}^{3+}$ oxidation in the environment make unlikely the evolution of $\mathrm{Cr}$ from $\mathrm{RM}$ to toxic $\mathrm{Cr}^{6+}$ (Burke et al. 2012).

Initially, the concentration of $\mathrm{Cr}$ leached to water exceeded largely $(\sim 38$-fold $)$ the WHO drinking water guideline (set at $50 \mu \mathrm{g} / \mathrm{L}$ ), but the $\mathrm{Cr}$ concentrations quickly dropped-in parallel to the SS concentration-to permissible and almost undetectable levels after passage of $\sim 2 \mathrm{PVF}$, and they did not increased hereinafter when acetic acid solutions were permeated (Fig. 5h). These suggest that the initial high effluent $\mathrm{Cr}$ concentration actually corresponds with suspended particulate matter and agrees with the occurrence of colloidal $\mathrm{Cr}(\mathrm{OH})_{3}$ species as described by Milačič et al. (2012). The maximum effluent $\mathrm{Cr}$ concentration was well below the US EPA TCLP limit ( $5 \mathrm{mg} \mathrm{Cr} / \mathrm{L}$ ), and after $\sim 2 \mathrm{PVF}$ (and herein), Cr concentrations were very low (below WHO threshold) and similar to that extracted from the RM by the TCLP method $(\sim 40 \mu \mathrm{g} / \mathrm{L})$ (Rubinos and Barral 2013). Similar metal release behaviour was found for the RM exposed to 20 and $40 \%$ acetic acid solutions, but the concentrations of leached $\mathrm{Cr}$ and $\mathrm{Fe}$ were slightly higher, accordingly to the higher effluent SS concentration (Table 6), lower permeated PVF and stronger acidity of the liquids.

Other analysed metals in the effluents were $\mathrm{Mn}, \mathrm{Ni}$, and $\mathrm{Cd}$, but they were not detected in none of the leachates. These results show that the trace metals are mostly as inert forms tightly bound in the RM matrix, hence poorly mobilised, which agrees with previous findings (Rubinos and Barral 2013). Nevertheless, it is advisable that the buffering capacity of the RML would not be exhausted to avoid undesirable trace metal release, which is enhanced once equilibrium $\mathrm{pH}$ decreases below 2 (Rubinos and Barral 2013). In practice, as we pointed out before, this situation is unlikely due to the extremely high ANC of the RM.

Permeation with n-heptane and trichloroethylene (TCE)

Neither diluted heptane $(53 \mathrm{mg} / \mathrm{L})$ nor TCE $(1100 \mathrm{mg} / \mathrm{L})$ increased the $k$ of the RML (Table 8), which agrees with the absence of effects on index properties of the RM. The effluent quality analyses after percolation of diluted heptane or TCE were consistent with the absence of effects on $k$ of the RML, but it must be stated that final effluent/ influent TOC ratios did not equal to 1 (Table 8), likely due to the well-known high adsorption capacity of RM of organic chemicals (Wang et al. 2008) and the low influent organics concentration relative to the RM mass in the specimen. Attempts to permeate the water-saturated RML 
Table 8 Summary of permeability results for the red mud permeated with pure and diluted heptane or trichloroethylene (TCE)

\begin{tabular}{llllll}
\hline Permeant & $K_{\mathrm{f}}(\mathrm{cm} / \mathrm{s})$ & $k_{\mathrm{f}}\left(\mathrm{cm}^{2}\right)$ & PVF & $k_{\text {korg }} / k_{\mathrm{w}}$ & $\mathrm{TOC}_{\mathrm{e}} / \mathrm{TOC}_{\mathrm{i}}$ \\
\hline Heptane & & & & \\
Water & $3.13^{\mathrm{a}} \times 10^{-7}$ & $2.89^{\mathrm{a}} \times 10^{-12}$ & $5.6^{\mathrm{a}}$ & & \\
& $4.05^{\mathrm{b}} \times 10^{-7}$ & $3.84^{\mathrm{b}} \times 10^{-12}$ & $3.6^{\mathrm{b}}$ & & 0.6 \\
$53 \mathrm{mg} / \mathrm{l}$ heptane & $3.37 \times 10^{-7}$ & $3.18 \times 10^{-12}$ & 8.2 & 1.1 & \\
Pure heptane & $\sim 0$ & $\sim 0$ & $\sim 0$ & & \\
TCE & & & & \\
Water & $2.79^{\mathrm{a}} \times 10^{-7}$ & $2.57^{\mathrm{a}} \times 10^{-12}$ & $4.5^{\mathrm{a}}$ & & \\
& $2.70^{\mathrm{b}} \times 10^{-7}$ & $2.49^{\mathrm{b}} \times 10^{-12}$ & $4.3^{\mathrm{b}}$ & $\mathrm{b}$ & \\
$1100 \mathrm{mg} / \mathrm{L} \mathrm{TCE}$ & $3.18 \times 10^{-7}$ & $2.99 \times 10^{-12}$ & 6.7 & 1.1 & \\
TCE & $\sim 0$ & $\sim 0$ & $\sim 0$ & & \\
\hline
\end{tabular}

$K_{\mathrm{f}}$, final hydraulic conductivity; $k_{\mathrm{f}}$, final intrinsic permeability; $P V F$, pore volumes permeated; $k_{\mathrm{korg}} / k_{\mathrm{w}}$, ratio between intrinsic permeability for organic chemical solutions (hepatne or TCE) and water; $T O C_{\mathrm{e}} /$ $T O C_{\mathrm{i}}$, effluent-to-influent total organic carbon ratio

a Baseline hydraulic conductivity of the red mud specimen permeated with organic at its solubility limit in water

b Baseline hydraulic conductivity of the red mud specimen permeated with pure organic with pure heptane or TCE were unsuccessful at the low hydraulic gradient $i$ of the tests, probably due to the surface tension between the immiscible organics and water.

Regarding metal leaching (patterns not shown), $\mathrm{Fe}$ and Si leaching was negligible, while the initially high effluent concentrations of $\mathrm{Al}$ (8.1-9.0

$\mathrm{mg} / \mathrm{L})$ and $\mathrm{Cr}(0.75-1.20 \mathrm{mg} / \mathrm{L})$ quickly dropped to undetectable levels as the SS concentration decreased from $12-14$ to $3 \mathrm{mg} / \mathrm{L}$ after $\sim 2 \mathrm{PVF}$ of water flowed through the RML, and did not increase hereinafter. The permeation with the diluted organics did not enhance metal leaching, as expected from the neutral $\mathrm{pH}$ of such solutions and the measured effluent $\mathrm{pHs}$ (essentially constant at $\mathrm{pH} \sim 9.5$ to $10)$.

\section{Permeation with calcium chloride and seawater}

Neither $1-5 \%(\mathrm{w} / \mathrm{v}) \quad \mathrm{CaCl}_{2}$ solutions nor seawater increased the $k$ of the compacted RM during the complete permeation period (63 days) (Fig. 6, Table 9), which suggests a high resistance of RMLs against the detrimental effect of $\mathrm{CaCl}_{2}$ and seawater on hydraulic conductivity.

The effect of inorganic solutions on hydraulic conductivity is based on their effect on the diffuse double layer causing flocculation or dispersion, shrinkage, or swelling (van Olphen 1963; Meggyes and Holzlöhner 1995; Spagnoli et al. 2010). The mechanism of action of $\mathrm{Ca}^{2+}$ on sodic soils is based on the replacement of $\mathrm{Na}^{+}$by $\mathrm{Ca}^{2+}$, which increases the hydraulic conductivity, because the adsorption of higher valence ions causes compression of the diffuse double layer (DDL) and the flocculation of the particles (USEPA 1988). Hence, the absence of noticeable effects of $\mathrm{CaCl}_{2}$ on the $k$ of the RML may be explained considering the particular cation exchange properties of
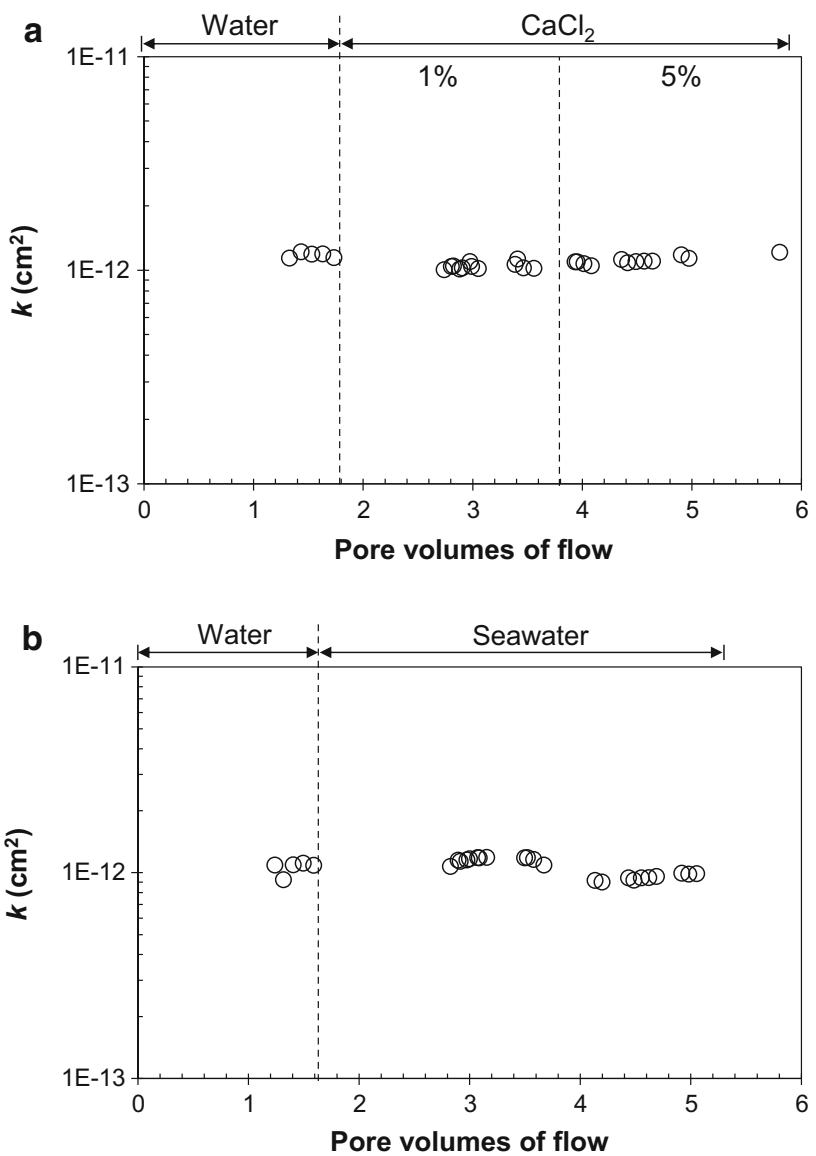

Fig. 6 Intrinsic permeability $k$ versus pore volumes of flow for compacted red mud permeated with a 1 and $5 \%(\mathrm{w} / \mathrm{v}) \mathrm{CaCl}_{2}$ solutions and $\mathbf{b}$ seawater

RM. Wong and Ho (1995) have shown that CECs of RM determined by using $\mathrm{K}^{+}$and $\mathrm{NH}_{4}^{+}$were significantly higher than those obtained using $\mathrm{Ca}^{2+}$ and $\mathrm{Ba}^{2+}$, whereas 
Table 9 Summary of permeability results for the red mud permeated with $\mathrm{CaCl}_{2}$ solutions or seawater

\begin{tabular}{llllll}
\hline Permeant & $K_{\mathrm{f}}(\mathrm{cm} / \mathrm{s})$ & $k_{\mathrm{f}}\left(\mathrm{cm}^{2}\right)$ & $\mathrm{PVF}$ & $k_{\mathrm{Ca}-\mathrm{Sw}} / k_{\mathrm{w}}$ & $\mathrm{EC}_{\mathrm{e}} / \mathrm{EC}_{\mathrm{i}}$ \\
\hline Calcium chloride & & & & \\
$\quad$ Water & $1.24 \times 10^{-7}$ & $1.14 \times 10^{-12}$ & 1.8 & - & - \\
$1 \% \mathrm{CaCl}_{2}$ & $1.06 \times 10^{-7}$ & $1.02 \times 10^{-12}$ & 3.8 & 0.9 & 1.00 \\
$5 \% \mathrm{CaCl}_{2}$ & $1.17 \times 10^{-7}$ & $1.21 \times 10^{-12}$ & 5.8 & 1.1 & 1.08 \\
Seawater & & & & - & - \\
$\quad$ Water & $1.18 \times 10^{-7}$ & $1.09 \times 10^{-12}$ & 1.6 & 0.9 & 1.00 \\
Seawater & $1.00 \times 10^{-7}$ & $9.88 \times 10^{-13}$ & 5.1 & \\
\hline
\end{tabular}

$K_{\mathrm{f}}$, final hydraulic conductivity; $k_{\mathrm{f}}$, final intrinsic permeability; $P V F$, pore volumes permeated; $k_{\mathrm{Ca}-\mathrm{Sw}} / k_{\mathrm{w}}$, ratio between intrinsic permeability for $\mathrm{CaCl}_{2}$ solutions or seawater and water; $E C_{\mathrm{e}} / E C_{\mathrm{i}}$, effluent-to-influent electrical conductivity ratio the $\mathrm{Na}^{+}$originally present in $\mathrm{RM}$ is preferentially adsorbed by RM over other divalent cations. This behaviour is attributed to the presence of zeolitic minerals in RM, which are characterised by a cavity-like porous structure.

Previous studies confirmed that the RM has a higher exchange affinity for monovalent $\mathrm{Na}^{+}$than divalent $\mathrm{Ca}^{2+}$ ions and that the later has limited ability to displace $\mathrm{Na}^{+}$ ions from the zeolitic exchange sites of the RM-where a major fraction of exchangeable $\mathrm{Na}^{+}(\sim 64 \%)$ is located (Rubinos 2008)—which are not easily available to exchange with $\mathrm{Ca}^{2+}$. In fact, the extraction of $\mathrm{Na}^{+}$from the $\mathrm{RM}$ with $\mathrm{Ca}^{2+}$ is kinetically a slow process, with a maximum $\sim 50 \%$ of the total $\mathrm{Na}^{+}\left(\sim 150 \mathrm{cmol}_{\mathrm{c}} / \mathrm{kg} \mathrm{RM}\right)$ displaced after extensive leaching with $0.5 \mathrm{M} \mathrm{CaCl}_{2}$ (Rubinos 2008).

Considering the dry density and porosity of the RM specimen, the volume of $\mathrm{CaCl}_{2}$ solution percolated during the permeation test $(\sim 175 \mathrm{~mL})$, and that $1 \mathrm{~mol}$ of $\mathrm{Ca}^{2+}$ exchanges with $2 \mathrm{~mol}$ of $\mathrm{Na}^{+}$ions, the maximum amount of $\mathrm{Na}^{+}$exchanged with $\mathrm{Ca}^{2+}$ during the permeation with $\mathrm{CaCl}_{2}$ was calculated as $\sim 8 \mathrm{cmol} \mathrm{Na}^{+}$, which accounts for $\sim 30 \%$ of total exchangeable $\mathrm{Na}^{+}$present in the $\mathrm{RM}$ specimen (assuming that all percolated $\mathrm{Ca}^{2+}$ ions were able of exchanging with $\mathrm{Na}^{+}$of the RM). Due to this, the effect of $\mathrm{CaCl}_{2}$ on DDL thickness of the RM was limited, and consequently the RML maintained its homogeneous dispersed state and its low $k$. The absence of detrimental effects of $\mathrm{CaCl}_{2}$ on $k$, as could be inferred from the slightly enhanced sedimentation rate in the salt, suggests that compaction counteracts the effect of $\mathrm{CaCl}_{2}$ on the DDL and mechanically stabilizes the RML.

In the case of seawater, that contains other cations (mainly $\mathrm{Mg}^{2+}$ and $\mathrm{K}^{+}$) besides $\mathrm{Ca}^{2+}$ with equivalent (for $\mathrm{Mg}^{2+}$ ) or higher ( $\sim 2$-fold) (for $\mathrm{K}^{+}$) ability to displace $\mathrm{Na}^{+}$ from RM, the maximum percentages of displaced $\mathrm{Na}^{+}$ after permeation were calculated as $\sim 0.5,0.9$ and $4.8 \%$ of total exchangeable $\mathrm{Na}^{+}$, by exchanging with $0.01 \mathrm{M} \mathrm{K}^{+}$, $0.01 \mathrm{M} \mathrm{Ca}^{2+}$ and $0.05 \mathrm{M} \mathrm{Mg}^{2+}$ initial concentrations in the seawater, respectively. Therefore, the poor $\mathrm{Na}^{+}$ displacement $(\sim 6.5 \%$ of total) supports the absence of detrimental effects of seawater on $k$ of the RML. The chemistry of the interaction of RM and seawater has been extensively studied (McConchie et al. 1999; Menzies et al. 2004; Rai et al. 2013). Seawater neutralises the alkalinity of RM through precipitation of $\mathrm{Mg}-\mathrm{Ca}-$, and Al-hydroxide and (hydroxi-)carbonate minerals, where the formation of hydrotalcite-like compounds assist in the reduction of dissolved metals in the liquor (Menzies et al. 2004; Palmer and Frost 2009). Seawater neutralisation does not eliminate hydroxide from the RM but converts the readily soluble, strongly caustic residual alkalinity into less soluble, weakly alkaline solids, without decreasing the ANC of RM (Rai et al. 2013). The process essentially consists in the transformation of soluble hydroxyls and carbonates in lowsolubility mineral precipitates. Hydroxyl ions of RM are neutralised by reaction with $\mathrm{Mg}^{2+}$ to form brucite $\left(\mathrm{Mg}_{3}(-\right.$ $\left.\mathrm{OH})_{6}\right)$ and hydrotalcite $\left(\mathrm{Mg}_{6} \mathrm{Al}_{2} \mathrm{CO}_{3}(\mathrm{OH})_{16} \cdot 4 \mathrm{H}_{2} \mathrm{O}\right)$, by precipitation of boehmite $(\mathrm{AlOOH})$ and gibbsite $\left(\mathrm{Al}(\mathrm{OH})_{3}\right)$, or by reaction with seawater $\mathrm{Ca}^{2+}$ to form $\left(\mathrm{Ca}_{2} \mathrm{Al}(\mathrm{OH})_{7} \cdot 3 \mathrm{H}_{2} \mathrm{O}\right)$ and p-aluminohydrocalcite $\left(\mathrm{CaAl}_{2}(-\right.$ $\left.\mathrm{CO}_{3}\right)_{2}(\mathrm{OH})_{4} \cdot 3 \mathrm{H}_{2} \mathrm{O}$ ], whereas the carbonate and bicarbonate alkalinity of the $\mathrm{RM}$ is removed primarily by reaction with Ca to form aragonite and calcite (McConchie et al. 1999). These reactions greatly reduce the $\mathrm{pH}$ of $\mathrm{RM}$ to $\sim 8-8.6$.

The analysis of the effluents showed that the seawater effluent $\mathrm{pH}$ followed a downward trend from $\sim 10$ to a stable $\mathrm{pH} \sim 8.2$, whereas the $\mathrm{pH}$ pattern for the $\mathrm{CaCl}_{2}$ effluents was similar, but the final $\mathrm{pH}$ value was $\sim 1$ unit lower $(\mathrm{pH} \sim 7)$ than for seawater (Fig. 7). Interestingly, these $\mathrm{pHs}$ almost equalled the $\mathrm{pH}$ of seawater $(\mathrm{pH} 8.1)$ and $5 \% \mathrm{CaCl}_{2}$ (pH 6.8) influents, while the $\mathrm{EC}$ of either 1 or $5 \% \mathrm{CaCl}_{2}$ and seawater effluents practically matched the influent $\mathrm{EC}$ values $\left(\mathrm{EC}_{\mathrm{i}}=16.7,67.0\right.$ and $54.1 \mathrm{mS} / \mathrm{cm}$, respectively) suggesting attainment of chemical equilibrium conditions at the end of tests period (final EC ratios 1) (Table 9, Fig. 7).

Regarding the leaching of metals, the initial high $\mathrm{Al}$ concentrations decreased to low values $(<0.5 \mathrm{mg} / \mathrm{L})$ after 

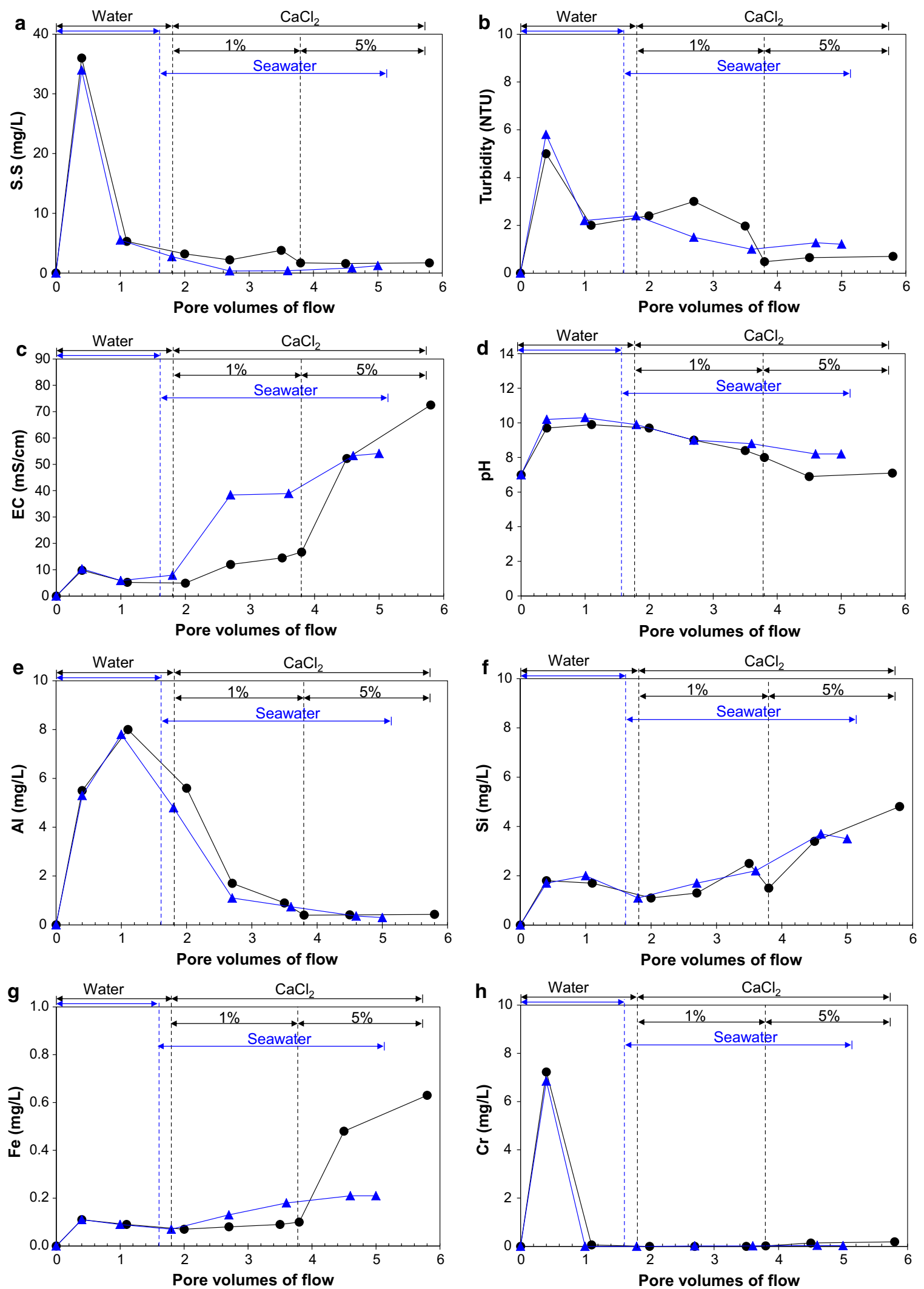

Fig. 7 Characteristics of the effluent from the red mud permeated either with $\mathrm{CaCl}_{2}$ solutions (black circles) or seawater (blue triangles). a Suspended solids (S.S.) concentration, b turbidity,

c electrical conductivity (EC), d $\mathrm{pH}$, e $\mathrm{Al}, \mathbf{f ~} \mathrm{Si}, \mathbf{g} \mathrm{Fe}$ and $\mathbf{h} \mathrm{Cr}$ concentrations, as a function of pore volumes of flow 
3.5 PVF for both salt solutions. Conversely, increasing effluent concentrations of $\mathrm{Si}$ and $\mathrm{Fe}$ were found as salt solutions were permeated (Fig. 7). Particularly, permeation with $5 \% \mathrm{CaCl}_{2}$ resulted in an increase (up to $\sim 6$-fold) of the effluent $\mathrm{Fe}$ concentration, but the cumulative amounts of $\mathrm{Fe}$ leached accounted for a negligible percentage of the total $\mathrm{Fe}$ in the RM and were structurally irrelevant. Concerning $\mathrm{Cr}$ leaching, its initial "first-wash" high concentration quickly dropped to undetectable levels as the solutions flowed and SS concentration dropped, whereas the observed upturn in $\mathrm{Cr}$ leaching (up to $0.19 \mathrm{mg} / \mathrm{L}$ final effluent concentration) following introduction of $5 \%$ $\mathrm{CaCl}_{2}$ is noticeable (Fig. 7). Even though the final $\mathrm{Cr}$ concentration in $\mathrm{CaCl}_{2}$ leachates was much lower than the upper TCLP threshold, it exceeded ( $\sim 4$-fold) the WHO drinking water established guideline. $\mathrm{CaCl}_{2}$ extracts somewhat greater amounts of metals than seawater, probably because of its slightly more acidic $\mathrm{pH}(\mathrm{pH} \sim 6.6$ to 6.8) or the ability of $\mathrm{CaCl}_{2}$ to extract metals due to chloride/metal complex formation (Ure 1996).

\section{Conclusion}

The results show that, in general, the RML exhibits a high resistance against chemical attack by different-type chemicals of waste storage impoundments. The studied chemicals affected the geotechnical and hydraulic properties of the RML in a different manner, and their effect was strongly dependent on its concentration. Atterberg limits results showed that neutral polar methanol reduced the plasticity of the RM only at concentrations $\geq 80 \%$ by volume; however, the permeability tests showed that such methanol concentration did not detrimentally affect the "short-term" $k$ of the RML, likely due to the stabilising effect of compaction on the RM. Acetic acid at concentrations $>40 \%$ decreased the PI and increased the settlement rate of the RM; conversely, lower concentrations induced dispersion of the RM. Permeation of the RM with $40 \%$ acetic acid caused the flow ceased, but prolonged exposure to the acid detrimentally affected the structure of the RML. Conversely, permeation of a $\mathrm{pH} 2$ acetic acid solution progressively decreased $k$ to values lower than for water, as it was neutralised.

Neither heptane nor TCE at their solubility limits affected the plasticity, sedimentation behaviour and $k$ of the RML, suggesting that low concentrations of apolar organics, as may be found in most waste leachates, would not affect the integrity of the RML. In contrast, all tested organics in pure form greatly reduced (acetic acid) or even suppressed (methanol, TCE, heptane) the plasticity and caused the immediate settlement and aggregation of RM, suggesting a high detrimental impact on the RML. As precautionary measure, use of RMLs for containment of pure low-dielectric-constant organics is not advisable. The RML was greatly resistant to inorganic salt solutions, as neither $\mathrm{CaCl}_{2}$ nor seawater detrimentally affected the RML hydraulic behaviour.

Regarding environmental compatibility of the RML, some concerning undesirable leaching of metals (primarily $\mathrm{Al}$ and $\mathrm{Cr}$ ) was initially found in water, acetic acid, and $5 \% \mathrm{CaCl}_{2}$ leachates, whose $\mathrm{Al}$ and $\mathrm{Cr}$ concentrations largely exceeded the WHO drinking water standards. Nevertheless, metal concentration dropped to undetectable levels as liquids were permeated, the SS concentration decreased, and the effluents became clearer. Hence, the removal of SS from the RML effluent is recommended to minimise metal outputs. The negligible dissolution of $\mathrm{Fe}$ was noteworthy, since it controls and limits the mobility of trace metals in the RM. Nevertheless, because RM neutralises acids through dissolution of its constituents, effluent characteristics surveillance must be implemented when RMLs are used to contain or attenuate acidic waste liquids.

Acknowledgments The authors acknowledge ALCOA of Spain for kindly let us to sample the red mud used in the study.

\section{References}

Aldaeef AA, Rayhani MT (2014) Hydraulic performance of compacted clay liners (CCLs) under combined temperature and leachate exposures. Waste Manage 34:2548-2560

Amadi AA, Eberemu AO (2013) Potential application of lateritic soil stabilized with cement kiln dust (CKD) as liner in waste containment structures. Geotech Geol Eng 31:1221-1230

Andreas L, Diener S, Lagerkvist A (2014) Steel slags in a landfill top cover-Experiences from a full-scale experiment. Waste Manage 34:692-701

Anton A, Rékási M, Uzinger N, Széplábi G, Makó A (2012) Modelling the potential effects of the Hungarian red mud disaster on soil properties. Water Air Soil Pollut 223:5175-5188

Arasan S (2010) Effect of chemicals on geotechnical properties of clay liners: a review. Res J Appl Sci Eng Technol 2:765-775

Atun G, Hisarli G (2000) A study of surface properties of red mud by potentiometric method. J Colloid Interface Sci 228:40-45

Benson CH, Othman MA (1993) Hydraulic and mechanical characteristics of a compacted municipal solid waste compost. Waste Manage Res 11:127-142

Benson C, Zhai H, Wang X (1994) Estimating hydraulic conductivity of compacted clay liners. J Geotech Eng 120:366-387

Benson CH, Ören AH, Gates WP (2010) Hydraulic conductivity of two geosynthetic clay liners permeated with a hyperalkaline solution. Geotext Geomembr 28:206-218

Benson CH, Jo HY, Musso T (2015) Hydraulic conductivity of organoclay and organoclay-sand to fuels and organic liquids. J Geotech Geoenviron Eng 141(2):04014094. doi:10.1061/ (ASCE)GT.1943-5606.0001194

Bhatnagar A, Vilar VJP, Botelho CMS, Boaventura RAR (2011) A review of the use of red mud as adsorbent for the removal of toxic pollutants from water and wastewater. Environ Technol $32: 231-249$ 
Bondy SC (2010) The neurotoxicity of environmental aluminum is still an issue. NeuroToxicol 31:575-581

Bowders JJ, Daniel DE (1987) Hydraulic conductivity of compacted clay to dilute organic chemicals. J Geotech Eng ASCE 113:1432-1448

Bowders JJ, Daniel DE, Broderick GP, Liljestran HM (1986) Methods for testing the compatibility of clay liners with landfill leachate. In: Petros JK, Lacy WJ, Conway RA (eds) Hazardous and Industrial Solid Waste Testing: Fourth Symposium, ASTM STP 886. American Society for Testing and Materials, Philadelphia, pp 233-250

Broderick GP, Daniel DE (1990) Stabilizing compacted clay against chemical attack. J Geotech Eng 116:1549-1567

Burke IT, Mayes WM, Peacock CL, Brown AP, Jarvis AP, Gruiz K (2012) Speciation of arsenic, chromium, and vanadium in red mud samples from the Ajka spill site, Hungary. Environ Sci Technol 46:3085-3092

Çoruh S, Ergun ON (2010) Use of fly ash, phosphogypsum and RM as a liner material for the disposal of hazardous zinc leach residue waste. J Hazard Mater 173:468-473

Daniel DE (1993) Geotechnical practice for waste disposal. Chapman \& Hall, London

Di Matteo L, Bigotti F, Ricco R (2011) Compressibility of kaolinitic clay contaminated by ethanol-gasoline blends. J Geotech Geoenviron Eng 137:846-849

European Union Council Directive 1999/31/EC of 26 April 1999 on the landfill of waste, Annex 1: general requirements for all classes of landfills. (1999). Official Journal of the European Communities, L182:1-19

Foreman DE, Daniel DE (1986) Permeation of compacted clay with organic chemicals. J Geotech Eng 112:669-681

Frenkel H, Levy G, Fey MV (1992) Hydraulic conductivity and clay dispersion in clay-sand mixtures as affected by organic and inorganic anions. Clays Clay Miner 40:515-521

Gad SC (1989) Acute and chronic systemic chromium toxicity. Sci Total Environ 86:149-157

Gensemer RW, Playle RC (1999) The bioavailability and toxicity of aluminum in aquatic environments. Crit Rev Env Sci Tec 29:315-450

Gräfe M, Landers M, Tappero R, Austin P, Gan B, Grabsch A, Klauber C (2011) Combined application of QUEM-SEM and hard X-ray microscopy to determine mineralogical associations and chemical speciation of trace metals. J Environ Qual 40:767-783

Halim CE, Scott JA, Natawardaya H, Amal R, Beydoun D, Low G (2004) Comparison between acetic acid and landfill leachates for the leaching of $\mathrm{Pb}(\mathrm{II}), \mathrm{Cd}(\mathrm{II}), \mathrm{As}(\mathrm{V})$, and $\mathrm{Cr}(\mathrm{VI})$ from cementitious wastes. Environ Sci Technol 38:3977-3983

Hammond K, Mishra B, Apelian D, Blanpain B (2013) CR $^{3}$ communication. Red mud-A resource or a waste? JOM J Miner Metals Mater Soc 65:340-341

Hettiaratchi JPA, Hrudey SE, Smith DW, Sego DCC (1988) A procedure for evaluating municipal solid waste leachate components capable of causing volume shrinkage in compacted clay soils. Environ Technol Lett 9:23-34

Hettiaratchi JPA, Achari G, Joshi RC, Okoli RE (1999) Feasibility of using fly ash admixtures in landfill bottom liners or vertical barriers at contaminated site. J Environ Sci Health Pt A 34:1897-1917

Jo HY, Benson CH, Edil TB (2004) Hydraulic conductivity and cation exchange in non-prehydrated and prehydrated bentonite permeated with weak inorganic salt solutions. Clays Clay Miner 52:661-679

Jo HY, Benson CH, Shackelford CD, Lee JM, Edil TB (2005) Longterm hydraulic conductivity of a geosynthetic clay liner permeated with inorganic salt solutions. J Geotech Geoenviron Eng 131:405-417
Kalkan E (2006) Utilization of red mud as a stabilization material for the preparation of clay liners. Eng Geol 87:220-229

Khaitan S, Dzombak DA, Lowry GV (2009) Chemistry of the acid neutralization capacity of bauxite residue. Environ Eng Sci 26:873-881

Klauber C, Gräfe M, Power G (2011) Bauxite residue issues: II. Options for residue utilization. Hydrometallurgy 108:11-32

Koch D (2002) Bentonites as a basic material for technical base liners and site encapsulation cut-off walls. Appl Clay Sci 21:1-11

Kubota H, Tsuda S, Murata M, Yamamoto T, Tanaka Y, Makita T (1979) Specific volume and viscosity of methanol-water mixtures under high pressure. Rev Phys Chem Jpn 49:59-69

Kumar S, Stewart J (2003) Evaluation of Illinois pulverized coal combustion dry bottom ash for use in geotechnical engineering applications. J Energ Eng ASCE 129:42-55

Lee JM, Shackelford CD, Benson CH, Jo HY, Edil TB (2005) Correlating index properties and hydraulic conductivity of geosynthetic clay liners. $\mathrm{J}$ Geotech Geoenviron Eng 131:1319-1329

Liu Y, Naidu R, Ming H (2011) Red mud as an amendment for pollutants and liquid phases. Geoderma 163:1-12

Liu Y, Gates WP, Bouazza A (2013) Acid induced degradation of the bentonite component used in geosynthetic clay liners. Geotex Geomembr 36:71-80

Malusis MA, McKeehan MD (2013) Chemical compatibility of model soil-bentonite backfill containing multiswellable bentonite. J Geotech Geoenviron Eng 139:189-198

Mayes WM, Jarvis AP, Burke IT, Walton M, Feigl V, Klebercz O, Gruiz K (2011) Dispersal and attenuation of trace contaminants downstream of the Ajka bauxite residue (red mud) depository failure, Hungary. Environ Sci Technol 45:5147-5155

McConchie D, Clark M, Hanahan C, Fawkes R (1999) The use of seawater-neutralized bauxite refinery residue red mud in environmental remediation programs. In: Gaballah I, Hager J, Solozabal R (edS) Global symposium on recycling, waste treatment and clean technology, vol 1. The Minerals, Metals and Materials Society, San Sebastián

Meegoda NJ, Rajapakse RA (1993) Short-term and long-term permeabilities of contaminated clays. J Environ Eng ASCE 119:725-743

Meegoda NJ, Ratnaweera P (1994) Compressibility of contaminated fine grained soils. Geotech Test J 17:101-112

Meggyes T, Holzlöhner U (1995) Todayś landfill liners protecting tomorrowś environment. UTA International 1(95):84-92

Menzies NW, Fulton IM, Morrell WJ (2004) Seawater neutralization of alkaline bauxite residue and implications for revegetation. J Environ Qual 33:1877-1884

Milačič R, Zuliani T, Ščančar J (2012) Environmental impact of toxic elements in red mud studied by fractionation and speciation procedures. Sci Total Environ 426:359-365

Mitchell JK (1993) Fundamentals of soil behavior. Wiley, New York

Mosavat N, Nalbantoglu Z (2011) Permeation of compacted clay with organic fluids. Int J Min Reclamat Environ 25:313-320

Mosavat N, Nalbantoglu Z (2013) The impact of hazardous waste leachate on performance of clay liners. Waste Manage Res 31:194-202

Nhan CT, Graydon JW, Kirk DW (1996) Utilizing coal fly ash as a landfill barrier material. Waste Manage 16:587-595

Olgun M, Yildiz M (2010) Effect of organic fluids on the geotechnical behavior of a highly plastic clayey soil. Appl Clay Sci 48:615-621

Öman C, Hynning P (1993) Identification of organic compounds in municipal landfill leachates. Environ Pollut 80:265-271

Palmer SJ, Frost RL (2009) Characterisation of bauxite and seawater neutralized bauxite residue using XRD and vibrational spectroscopic techniques. J Mater Sci 44:55-63 
Palomino AM, Santamarina JC (2005) Fabric map for kaolinite: effects of $\mathrm{pH}$ and ionic concentration on behavior. Clays Clay Miner 53:211-223

Pansu M, Gautheyrou J (2006) Handbook on soil analysis: mineralogical, organic and inorganic methods. Springer, Berlin

Peterson SR, Gee GW (1985) Interactions between acidic solutions and clay liners: Permeability and Neutralization. In: Johnson AI, Frobel RK, Cavalli NJ, Pettersson CB (eds) Hydraulic barriers in soil and rock, ASTM STP 874. American Society for Testing and Materials, Philadelphia, pp 229-245

Rai S, Wasewar KL, Lataye DH, Mukhopadhyay J, Yoo CK (2013) Feasibility of red mud neutralization with seawater using Taguchi's methodology. Int J Environ Sci Technol 10:305-314

Rhoades JD (1982) Soluble salts. In: Klute A, Page AL, Sparks DL, Jacob HD, Clarke TG (eds) Methods of soil analysis. Part 2. Chemical and microbiological properties, 2nd edn. ASA and SSSA, Madison, pp 167-179

Rubinos DA (2008) Utilización de lodos rojos de bauxita en la contención e inactivación de residuos tóxicos y peligrosos. Ph.D. Dissertation, University of Santiago de Compostela

Rubinos DA, Barral MT (2013) Fractionation and mobility of metals in bauxite red mud. Environ Sci Pollut Res 20:7787-7802

Rubinos D, Spagnoli G, Barral MT (2015) Assessment of bauxite refining residue (red mud) as a liner for waste disposal facilities. Int J Min Reclamat Environ 29(6):433-452. doi:10.1080/ 17480930.2013.830906

Santamarina JC, Klein KA, Palomino A, Guimaraes MS (2002) Micro-scale aspects of chemo-mechanical coupling: interparticle forces and fabric. In: Di Maio C, Hueckel T, Loret B (eds) Chemo-mechanical coupling in clays: from nano-scale to engineering applications. Swets \& Zeitlinger, Lisse, pp 47-64

Shackelford CD, Benson CH, Katsumi T, Edil TB, Lin L (2000) Evaluating the hydraulic conductivity of GCLs permeated with non-standard liquids. Geotext Geomembr 18:133-161

Shackelford CD, Sevick GW, Eykholt GR (2010) Hydraulic conductivity of geosynthetic clay liners to tailings impoundment solutions. Geotext Geomembranes 28:149-162

Sivapullaiah PV, Lakshmikantha H (2004) Properties of fly ash as hydraulic barrier. Soil Sediment Contam 13:391-406

Spagnoli G, Fernández-Steeger T, Feinendegen M, Stanjek H, Azzam $R$ (2010) The influence of dielectric constant and electrolyte concentration of the pore fluids on the undrained shear strength of smectite. Soils Found 50:757-763
Spagnoli G, Rubinos D, Stanjek H, Fernández-Steeger T, Feinendegen M, Azzam R (2012) Undrained shear strength of clays as modified by pH variations. Bull Eng Geol Environ 71:135-148

Sridharan A, Rao VG (1975) Mechanisms controlling the liquid limit of clays. In: Proceedings Istanbul conference on SM and F.E (vol 1 , pp. 75-84)

Stern RT, Shackelford CD (1998) Permeation of sand-processed clay mixtures with calcium chloride solutions. J Geotech Geoenviron Eng 124:231-241

Stumm W, Morgan JJ (1996) Aquatic chemistry, 3rd edn. Wiley, New York

Taha MR, Kabir MH (2005) Tropical residual soil as compacted soil liners. Environ Geol 47:375-381

Ure AM (1996) Single extraction schemes for soil analysis and related applications. Sci Total Environ 178:3-10

USEPA (U.S. Environmental Protection Agency) (1988) Design, construction, and evaluation of clay liners for waste management facilities. EPA/530/SW-86/007F. U.S. Environmental Protection Agency, Cincinnati

van Olphen H (1963) An introduction to clay colloid chemistry. Interscience Publishers, New York

Wang S, Ang HM, Tadé MO (2008) Novel applications of red mud as coagulant, adsorbent and catalyst for environmentally benign processes. Chemosphere 72:1621-1635

WHO (World Health Organisation) (2011) Guidelines for drinkingwater quality, 4th edn. World Health Organisation, Geneva

Wong JW, Ho GE (1988) Neutralization and cation dissolution characteristics of bauxite refining residue. In: Varma MM, Johnson Jr JH (eds) Hazardous and industrial waste: proceedings of the 20th Mid-Atlantic industrial waste conference. Hazardous Materials Control Research Institute, Silver Spring, MD, USA, pp 247-264

Wong JW, Ho GE (1995) Cation exchange behavior of bauxite refining residues from Western Australia. J Environ Qual 24:461-466

Yilmaz H (2002) Excess properties of alcohol-water systems at 298.15 K. Turk J Phys 26:243-246

Yilmaz G, Yetimoglu T, Arasan S (2008) Hydraulic conductivity of compacted clay liners permeated with inorganic salt solutions. Waste Manage Res 26:464-473 